\title{
Nitrite reduction on a multimetallic porphyrin/polyoxotungstate layer-by-layer modified electrodes
}

Macarena Garcia ${ }^{a}$, Jessica Honores ${ }^{b}$, Diego Quezada ${ }^{b}$, Carlos Díaz $^{b}$, Paulina Dreyse ${ }^{c}$, Freddy Celis ${ }^{d}$, Clifford P. Kubiak ${ }^{e}$, Gabrielle Canzi ${ }^{e}$, Fernando Guzmán $^{f}$, María J. Aguirre ${ }^{a}$ and Mauricio Isaacs ${ }^{b^{*}}$

a) Facultad de Química y Biología, Departamento de Química de los Materiales, Universidad de Santiago de Chile, Av. Bernardo O’Higgins 3363, Estación Central, Casilla 40- correo 33, Santiago, Chile.

b) Departamento de Química Inorgánica, Facultad de Química, Pontificia Universidad Católica de Chile, Av. Vicuña Mackenna \#4860, Macul, Santiago, Chile.

c) Departamento de Química, Universidad Técnica Federico Santa María, Avenida España \#1680, Valparaíso, Chile.

d) Centro de Estudios Avanzados (C.E.A.), Facultad de Ciencias Naturales y Exactas, Departamento de Química, Universidad de Playa Ancha, Leopoldo Carvallo \#270, Valparaíso, Chile

e) Chemistry and Biochemistry Department, University of California, San Diego, 9500 Gilman Drive MC 0358, La Jolla CA 92093, USA.

f) Departamento de Física, Facultad de Ciencias Físicas y Matemáticas, Universidad de Chile, Beauchef 850, Santiago, Chile

"e-mail: $\underline{\text { misaacs@uc.cl }}$ 
KEYWORDS: Layer-by-Layer, modified electrode, nitrite reduction, photoelectrochemistry, IR Spectro-electrochemistry.

\section{ABSTRACT}

Electro and photoelectrochemical reduction of nitrite in aqueous solution was studied using a multielectrocatalysts modified ITO electrode. ITO modification was carried out using the layer-by-layer (LBL) method, where sequential electrostatic assemblies were formed using a $\quad \mu$-(meso-5,10,15,10-tetra(pirydil)porphyrin)tetrakis $\quad\{$ bis(bipyridine)chloride ruthenium (II) $\}[\mathrm{MTRP}]^{\mathrm{n}+}$, coordinated in its central cavity with $\mathrm{Mn}(\mathrm{III}), \mathrm{Zn}(\mathrm{II})$ or $\mathrm{Ni}(\mathrm{II})$ as a cationic layer, and polyoxotungstate $\left[\mathrm{SiW}_{12} \mathrm{O}_{40}\right]^{4-}$ as the anionic layer. Electrochemical measurements and UV-vis spectroscopy were used to monitor the modification process. Optimal results were obtained when three layers were deposited onto the ITO surface and were stable in aqueous solution. The order of the multilayer formation was explored by comparing a modified electrode where $[\mathrm{Zn}(\mathrm{II}) \mathrm{TRP}]^{4+}$ was the outermost layer with an electrode where $\left[\mathrm{SiW}_{12} \mathrm{O}_{40}\right]^{4-}$ was the outer layer. Results show that the best performing electrode is one with $\left[\mathrm{SiW}_{12} \mathrm{O}_{40}\right]^{4-}$ as the outer layer. Nitrite reduction on these electrode surfaces was studied in dark conditions and under light irradiation. Potential controlled electrolysis experiments were also performed, finding hydroxylamine, hydrazine and ammonia as the reduction products in dark conditions. Under light irradiation, only hydrazine and ammonia were found and, we observed an increase in the amount of obtained product. In this case, the electrolysis was carried out $150 \mathrm{mV}$ less and half of time than in dark conditions. These results show that the combination of light and potential give rise to an improvement in the electrocatalytic properties of the modified electrodes. Continuous photolysis and IR spectroelectrochemical experiments were carried out to 
determinate the nature of this phenomena, evidencing the formation of an intermediary species between nitrite and $[\mathrm{Mn}(\mathrm{III}) \mathrm{TRP}]^{5+}$ 


\section{INTRODUCTION}

Nitrite ion, $\mathrm{NO}_{2}^{-}$, is an intermediate species in the nitrogen cycle resulting from the oxidation of ammonia or from reduction of nitrate [1,2]. Nitrite is strongly related to human life because it is used as a preservative of foods and a color fixative for meats [3]. On the other hand, atmospheric nitrite is oxidized to $\mathrm{HNO}_{3}$ by $\mathrm{OH} \bullet$ radicals. Nitric acid is a component of acid rain, which in contact with soils, generates nitrites and nitrates increasing their concentration in this complex environmental matrix $[4,5]$ and in ground water $[3,4]$. The removal or conversion of nitrites and nitrates in water to harmless compounds, is one of the current issues in environmental remediation [3].

The influence of nitrite in human health has been recognized since nitrite contained in drinking water and foods is a serious health risk for human beings such as metahemoglobinemia, where $\mathrm{Fe}(\mathrm{II})$ present in hemoglobin $(\mathrm{Hb})$ protein is oxidized to $\mathrm{Fe}(\mathrm{III})$ generating methahemoglobin (metHb) which is incapable of perform its physiologic functions [6]. On the other hand, nitrite ion is able to react with secondary amines or amides to form nitrosamines or nitrosamides, that can act as carcinogenic agents [7].

Several analytical methods have been proposed to determine nitrite including spectrophotometry $[8,9]$ and chromatography $[10,11]$. Nitrite has been important from the point of view of electrochemistry, because is oxidized to nitrate and reduced to nitric oxide or other compounds [3]. In most common electrodic surfaces, nitrite reduction is thermodinamically favorable, but the charge transfer kinetics associated with the reaction is slow, and needs high overpotentials [2]. For this reason, the use of an electrocatalyst is necessary. In this sense, nitrite reduction has been reported using different kinds of 
modified surfaces with metals [12-14], metal oxides [15-18] and diferent types of transition metal complexes like porphyrins [5,19-25], phtalocyanines [26], corrols [27], cyclams [28] among others.

Recently Winther-Jensen et.al described a method to reduce nitrite using PEDOTbipyridinium-Fe-complex electrodes, finding that it is possible to reduce nitrite at $-0,65 \mathrm{~V}$ vs $\mathrm{Ag} / \mathrm{AgCl}$, in aqueous media, giving only ammonia as reaction product. The system selectivity have been explained in terms of the formation of an Fe-nitrosyl complex, which is reduced to ammonia in a five electron step, giving an important evidence about the effect of coordination chemistry in the design of an efficient electrocatalyst for the reduction of nitrite [29].

Polyoxometalates (POMs) are oligomeric aggregates formed by metal cations and bridged by oxygen atoms. Due to its unique structure POMs are very versatile compounds. Their properties such as size, redox chemistry, charge distribution and photochemical activity can be modulated according to its chemical composition; for these reasons their chemical reactivity has been studied in many applications such as biologic assays [30] or as catalysts in chemical reactions with technological interest [31].

POMs (heteropoly and isopolyoxometalates) have been used as material to modify electrodic surfaces, its activity in acid media toward the hydrogen evolution and oxygen [32], nitrite [33], bromate [34] and iodate reduction [35] have been tested.

Recently, Liu et.al [36], have reported the use of POM in hybrid fuel cells, which uses the previously mentioned catalyst to degrade biomass under light irradiation, and to reduce 
oxygen in the same device, showing the photoelectrocatalytic activity of this kind of clusters.

In 1993, Araki and coworkers synthesized the $\mu$-\{meso-5, 10, 15, 20-tetra (pyridyl) porphyrin $\}$ tetrakis $\{$ bis(bipyridine)chloride ruthenium(II) $\}\left(\mathrm{PF}_{6}\right)_{4}(\mathrm{TRP})$ and its respective metal complexes with $\mathrm{Co}(\mathrm{II}), \mathrm{Ni}(\mathrm{II})$ and $\mathrm{Zn}(\mathrm{II})$ [37] starting from a free base pyridyl porphyrin and the corresponding ruthenium complex. These kind of compounds have been previously used in a wide range of electrochemical studies including environmental and technological applications such as sulfite, nitrite, oxygen and carbon dioxide reduction using the above mentioned complexes as an homogeneous catalyst in several solvents [3842]. Its capacity to act as an efficient electrocatalyst is mainly due to the combination of the coordination and redox properties of porphyrins and the redox and photochemical properties of ruthenium polypyridyl substituents, which improve electron transfer, hence, this kind of compounds can be used to achieve multielectronic redox processes.

It was previously demonstrated that ITO electrodes modified with bilayers containing $\left[\mathrm{SiW}_{12} \mathrm{O}_{40}\right]^{4-}$ and tetraruthenated porphyrins present strong photoelectrocatalytic behavior toward carbon dioxide reduction, showing that at $-0,8 \mathrm{~V}$ vs $\mathrm{Ag} / \mathrm{AgCl}$ this kind of electrodes can lead to multielectronic reduction of $\mathrm{CO}_{2}$, producing high reduced compounds such as methanol, formic acid or formaldehyde in dark conditions; changing to a more selective product distribution when the system is under irradiation of 440nm [43].

In the present work multimetallic porphyrins/POMs films have been investigated toward the electrocatalytic reduction of nitrite. 


\section{EXPERIMENTAL}

\subsection{Chemical reagents}

All chemical reagents were of analytical grade or better. Silicontungstinic acid $\left[\mathrm{H}_{4} \mathrm{SiW}_{12} \mathrm{O}_{40}\right]$ and ammonium hexafluorophosphate were purchased from Fluka. Mn(III) acetate, $\mathrm{Zn}(\mathrm{II})$ acetate, $\mathrm{Ni}(\mathrm{II})$ acetate, 5,10,15,20-tetra pyridyl-21H, 23H-porphine, sodium perchlorate, tetrabuthylammoniun nitrite (TBAN), triethanolamine (TEA), and 2,2dipyridyl were purchased from Sigma-Aldrich. Lithium chloride was purchased from Fisher Scientific. Ruthenium (III) chloride trihydrate was purchased from Pressure Chemical Co. Sodium nitrite was purchased from Riedel-deHaën. N,N-dimethylformamide (DMF), ethanol, methanol, acetone, glacial acetic acid, deuterated acetonitrile and neutral alumina were purchased from Merck.

The synthesis of the precursor complex cis-dichloro (2,2-bipyridine) ruthenium (II) dihydrate was carried out based on a procedure previously described in the literature [44]. Supramolecular complexes $\mu-\{$ meso-5, 10, 15, 20-tetra (pyridyl) porphyrin $\}$ tetrakis $\{$ bis(bipyridine)chloride ruthenium(II) $\}\left(\mathrm{PF}_{6}\right)_{4}$ and its respective metal complexes with $\mathrm{Mn}(\mathrm{III}), \mathrm{Ni}(\mathrm{II})$ and $\mathrm{Zn}(\mathrm{II})$ defined as $[\mathrm{Mn}(\mathrm{III}) \mathrm{TRP}]^{5+},[\mathrm{Zn}(\mathrm{II}) \mathrm{TRP}]^{4+}$ and $[\mathrm{Ni}(\mathrm{II}) \mathrm{TRP}]^{4+}$ were prepared by a method described by Araki et al. [40,45-48]. The purity of these compounds was checked by optical absorption spectroscopy, elemental analysis and cyclic voltammetry. 


\subsection{Procedures}

Electrochemical experiments were carried out in a $\mathrm{CH}$ Instruments model 620B electrochemical workstation using a three-compartment Pyrex glass cell. An Indium Tin Oxide (ITO) electrode (Delta Technologies, MN U.S.A) was used as the working electrode with $\mathrm{Ag} / \mathrm{AgCl}(3 \mathrm{M} \mathrm{KCl})(\mathrm{CH}$ Instruments, TX, U.S.A.) as the reference and $\mathrm{Pt}$ wire as the counter electrodes respectively.

All potentials values informed in this work are quoted against $\mathrm{Ag} / \mathrm{AgCl}(3 \mathrm{MKCl})$ reference electrode. Photoelectrochemical experiments were carried out using a three compartment cell with a quartz window irradiated with light of $440 \mathrm{~nm}$, provided by a $500 \mathrm{~W}$ XenonMercury lamp system (Oriel Co) coupled to a monochromator (Jarrell Ash, Czerny-turner).

Controlled potential electrolysis experiments were carried out on a BASI POWER MODULE PWR-3 potentiostat. The experiments were performed in a gastight H type cell. UV-Visible data were recorded on a Shimadzu Multispec 1501 spectrophotometer.

IR-SEC measurements were carried out in a Bruker Equinox 55 spectrometer along with a Pine Biopotentiostat Model AFCBP1.

Continuous photolysis experiments were carried out on a sealed quartz cell irradiated with white light provides by a 500W Xenon-Mercury lamp system (Oriel Co).

AFM images were registered on a Bruker NanoScope Innova AFM along with NanoDrive v8.01 software.

All XPS spectra were obtained by a XPS spectrometer, Physical Electronic model 1257. 


\subsubsection{Preparation of the $[M T R P]^{n+} /\left[\mathrm{Si}_{12} \mathrm{O}_{40}\right]^{4-}$ bilayers film}

The ITO electrode was cleaned with methanol for one hour, and subsequently rinsed with deionized water. Modification process was carried out by a previously reported method $[43,49]$ A cleaned ITO electrode was dipped into a $0.5 \mathrm{mM}$ methanolic solution of $\mathrm{Ni}(\mathrm{II})$, $\mathrm{Zn}$ (II) or $\mathrm{Mn}(\mathrm{III})$ tetraruthenated porphyrin for four minutes. After that, the electrode surface was rinsed with deionized water to avoid surface excess. The "layer" modified ITO electrode was dipped into a $0.5 \mathrm{mM}$ solution of $\left[\mathrm{SiW}_{12} \mathrm{O}_{40}\right]^{4-}$ for four minutes. The "bilayer" modified electrode was rinsed and dried. The procedure was repeated three times, obtaining a $[\mathrm{MTRP}]^{\mathrm{n}+} /\left[\mathrm{SiW}_{12} \mathrm{O}_{40}\right]^{4-}$ bilayer modified electrode. For change the order in the bilayer formation, the previous preparation of the ITO was the same, but the ITO electrode was fist

dipped into the $\left[\mathrm{SiW}_{12} \mathrm{O}_{40}\right]^{4-}$ solution, rinsed and secondly dipped into the methanolic porphyrin solution.

The bilayer formation was monitored by UV-Vis spectroscopy and cyclic voltammetry.

The stability of the modified electrode was evaluated in a $0.1 \mathrm{M} \mathrm{NaClO} 4$ solution under potentiostatic conditions. The electrode potential was swept during 50 continuous cycles between $-0.9 \mathrm{~V}$ and $1.0 \mathrm{~V}$ for $[\mathrm{Zn}(\mathrm{II}) \mathrm{TRP}]^{4+} /\left[\mathrm{SiW}_{12} \mathrm{O}_{40}\right]^{4-}$ and $[\mathrm{Mn}(\mathrm{III}) \mathrm{TRP}]^{5+} /\left[\mathrm{SiW}_{12} \mathrm{O}_{40}\right]^{4-}$ bilayer modified electrode and between $-0.9 \mathrm{~V}$ and $1.2 \mathrm{~V}$ for $[\mathrm{Ni}(\mathrm{II}) \mathrm{TRP}]^{4+} /\left[\mathrm{SiW}_{12} \mathrm{O}_{40}\right]^{4-}$ bilayer modified electrode.

\subsubsection{Electrochemical reduction of nitrite}

The electroreduction process of nitrite was studied by linear sweep voltammetry (LSV) with $[\mathrm{MTRP}]^{\mathrm{n}+} /\left[\mathrm{SiW}_{12} \mathrm{O}_{40}\right]^{4-}$ modified electrode, in a $1 \mathrm{mM} \mathrm{NaNO}_{2}, 0.1 \mathrm{M} \mathrm{NaClO}_{4}$ aqueous solution, between $-0.1 \mathrm{~V}$ and $-0.9 \mathrm{~V}$ at $5 \mathrm{mV} \mathrm{s}^{-1}$. 


\subsubsection{Photoelectrochemical reduction of nitrite}

Photoelectrochemical reduction experiments were studied by LSV in a $1 \mathrm{mM} \mathrm{NaNO}_{2}, 0.1 \mathrm{M}$ $\mathrm{NaClO}_{4}$ aqueous solution, between $-0.1 \mathrm{~V}$ and $-0.9 \mathrm{~V}$ at $5 \mathrm{mVs}^{-1}$. For this study the electrode was $5 \mathrm{~cm}$ from the lamp where light of $440 \mathrm{~nm}$ had an intensity of $20 \mathrm{~mW} \mathrm{~cm}$.

\subsubsection{Controlled potential electrolysis}

Controlled potential electrolysis experiments were carried out using a three bilayer $[\mathrm{MTRP}]^{\mathrm{n}+} /\left[\mathrm{SiW}_{12} \mathrm{O}_{40}\right]^{4-}$ modified electrode and a $0.01 \mathrm{M} \mathrm{NaNO}, 0.1 \mathrm{M} \mathrm{NaClO}{ }_{4}$ aqueous solution. In dark conditions the experiment was carried out for 6 hours at $-0.8 \mathrm{~V}$. Under light irradiation the time of electrolysis was 3 hours and the potential was set at $-0.65 \mathrm{~V}$.

The analyses of aqueous products (hydroxylamine, hydrazine and ammonia) were carried out using previously reported methods [50-52].

\subsubsection{IR-Spectroelectrochemistry experiments for nitrite reduction}

The design of the IR spectroelectrochemical cell has been previously reported [53,54]. All spectroelectrochemical experiments were carried out in a deuterated acetonitrile solution with $1 \mathrm{mM}[\mathrm{MTRP}]^{\mathrm{n}+} 0.1 \mathrm{M}$ TBAH $0.1 \mathrm{M}$ TBAN. All solutions were prepared under an atmosphere of dry nitrogen in a dry box. Blank deuterated acetonitrile solution with $0.1 \mathrm{M}$ TBAH and TBAN were used for the FTIR solvent subtraction.

\subsubsection{Continuous Photolysis experiments for nitrite reduction}

Photolysis experiments were run in sealed quartz cell, containing a solution of $20 \mu \mathrm{M}$ of [MTRP $^{\mathrm{n}+}(\mathrm{M}=\mathrm{Mn}, \mathrm{Ni}$ or $\mathrm{Zn})$ in MeOH/TEA 99:1\%v/v. In these experiments the solution was irradiated with white light by five minutes, and then UV-vis spectrum was collected. 
This procedure was repeated five times until reach 25 minutes of irradiation in total. The experiment was repeated with new fresh solutions of $[\mathrm{MTRP}]^{\mathrm{n}+}$, containing in addition $1 \mathrm{mM}$ of tetrabutyl ammonium nitrite (TBAN) in the solution

\section{RESULTS}

\subsection{Preparation of $[\mathrm{MTRP}]^{n+} /\left[\mathrm{Si}_{12} \mathrm{O}_{40}\right]^{4-}$ bilayers}

Structures of $[\mathrm{MTRP}]^{\mathrm{n}+}$ and silicontungstate anion $\left[\mathrm{SiW}_{12} \mathrm{O}_{40}\right]^{4-}$ are shown in figure 1. Tetraruthenated porphyrin consist in a $\mu$-(meso-5,10,15,20tetra(pirydil)porphyrin) $\{$ bis(bipyridine)chloride ruthenium(II) $\}$ groups, coordinated with $\mathrm{Mn}(\mathrm{III}), \mathrm{Zn}(\mathrm{II})$ and $\mathrm{Ni}(\mathrm{II})$ in its central cavity. Silicontungstate anion consist in $12 \mathrm{WO}_{6}$ octahedron, each constituted by a W central atom, an unshared oxygen, bridging oxygens (corner-shared and edge shared) and a coordinating oxygen to the Si atom $[55,56]$.

Electrochemical behavior of $[\mathrm{MTRP}]^{\mathrm{n}+}$ in organic solvents has been previously characterized $[43,49]$ and presents a $\mathrm{Ru}^{\mathrm{III} / \mathrm{II}}$ redox process at positive potentials. Silicontungstate anion, exhibit in aqueous solution 5 redox processes that are been previously described [49,57].

On the other hand, UV-Visible spectra of $[\mathrm{MTRP}]^{\mathrm{n}+}$ has been reported and exhibit the characteristic Soret and Q bands of the porphyrin and a $\pi \rightarrow \pi^{*}$ transitions of the bipyridine ligands $[40,49,58]$ Polioxotungstate present only one transition at $262 \mathrm{~nm}$ attributable to a charge transfer $\mathrm{O} \rightarrow \mathrm{W}[49,59]$. 
Bilayers formation were carried out as it was described before in section 2.2.1 and was monitored by cyclic voltammetry and UV-Visible spectroscopy.

After each bilayer deposition, a voltammogram was recorded, in a $0.1 \mathrm{M} \mathrm{NaClO}_{4}$ solution between -0.9 and $1.0 \mathrm{~V}$ vs $\mathrm{Ag} / \mathrm{AgCl}$ for $[\mathrm{Mn}(\mathrm{III}) \mathrm{TRP}]^{5+} /\left[\mathrm{SiW}_{12} \mathrm{O}_{40}\right]^{4-}$ and $[\mathrm{Zn}(\mathrm{II}) \mathrm{TRP}]^{4+} /\left[\mathrm{SiW}_{12} \mathrm{O}_{40}\right]^{4-}$ and between -0.9 and $1.1 \mathrm{~V}$ vs $\mathrm{Ag} / \mathrm{AgCl}$ for $[\mathrm{Ni}(\mathrm{II}) \mathrm{TRP}]^{4+} /\left[\mathrm{SiW}_{12} \mathrm{O}_{40}\right]^{4-}$ bilayers modified electrode $(\mathrm{ME})$. All experiments were recorded at $100 \mathrm{mV} / \mathrm{s}$.

As it can be seen in Figure 2a, for the three ME, there is a linear relationship between Ipa of the $\mathrm{Ru}^{\mathrm{III} / \mathrm{II}}$ process of the porphyrin and the number of bilayers adsorbed on the ITO surface. This linear relation indicates that with the deposit of each bilayer the amount of electroactive material adsorbed increase. It is possible to see that $[\mathrm{Mn}(\mathrm{III}) \mathrm{TRP}]^{5+} /\left[\mathrm{SiW}_{12} \mathrm{O}_{40}\right]^{4-} \quad \mathrm{ME}$ reach the highest current value followed by $[\mathrm{Ni}(\mathrm{II}) \mathrm{TRP}]^{4+} /\left[\mathrm{SiW}_{12} \mathrm{O}_{40}\right]^{4-}$ and $[\mathrm{Zn}(\mathrm{II}) \mathrm{TRP}]^{4+} /\left[\mathrm{SiW}_{12} \mathrm{O}_{40}\right]^{4-} \mathrm{ME}$.

Results show that the absorbance of all transition bands increase with the number of bilayers. In figure $2 \mathrm{~b}$ it is possible to see the linear relationship between the absorbance at the Soret band and the number of bilayers adsorbed, showing that with each bilayer deposition the amount of chromophore on the electrode surface increases.

As in the cyclic voltammetry results, $[\mathrm{Mn}(\mathrm{III}) \mathrm{TRP}]^{5+} /\left[\mathrm{SiW}_{12} \mathrm{O}_{40}\right]^{4-} \mathrm{ME}$, reach the biggest absorbance values followed by $[\mathrm{Ni}(\mathrm{II}) \mathrm{TRP}]^{4+} /\left[\mathrm{SiW}_{12} \mathrm{O}_{40}\right]^{4-}$ and $[\mathrm{Zn}(\mathrm{II}) \mathrm{TRP}]^{4+} /\left[\mathrm{SiW}_{12} \mathrm{O}_{40}\right]^{4-}$ ME.

The differences in the current and absorbance values for each ME can be explained in terms of its thickness. Previous studies [49] showed that there was a difference in the values of 
current and absorbance between $[\mathrm{Mn}(\mathrm{III}) \mathrm{TRP}]^{5+} /\left[\mathrm{SiW}_{12} \mathrm{O}_{40}\right]^{4-}$ and $[\mathrm{Zn}(\mathrm{II}) \mathrm{TRP}]^{4+} /\left[\mathrm{SiW}_{12} \mathrm{O}_{40}\right]^{4-}$. Ten bilayers modified electrodes with $[\mathrm{Mn}(\mathrm{III}) \mathrm{TRP}]^{5+} /\left[\mathrm{SiW}_{12} \mathrm{O}_{40}\right]^{4-}$ are 3.6 times thicker than the analogous $[\mathrm{Zn}(\mathrm{II}) \mathrm{TRP}]^{4+} /\left[\mathrm{SiW}_{12} \mathrm{O}_{40}\right]^{4-}$. This difference has been explained in terms of formal chemical bonds produced in the time scale of the modification process between $\mathrm{Mn}$ (III) and $\mathrm{O}$ atoms present in the POM molecule as Raman spectroscopy revealed [49]. This formal interaction helps to increase the amount of electroactive material present in each bilayer, giving rise to the formation of a thicker film deposit onto the ITO electrode.

In order to characterize the chemical composition of the modified surface, XPS analysis was performed taking $[\mathrm{Mn}(\mathrm{III}) \mathrm{TRP}]^{5+} /\left[\mathrm{SiW}_{12} \mathrm{O}_{40}\right]^{4-}$ as a probe XPS measurements confirms the presence of $\mathrm{O}, \mathrm{C}, \mathrm{N}, \mathrm{W}, \mathrm{Si}, \mathrm{Cl}, \mathrm{Ru}$ and $\mathrm{Mn}$ in the film as it can be seen in Figure 3. The fitting on Mn high resolution spectra reveals two peaks, Mn 2p3/2 (641.3 eV) and 2p1/2 $(652.8 \mathrm{eV})$ that correspond to either $\mathrm{Mn}^{2+}$ or $\mathrm{Mn}^{3+}$ (see supporting information). Also, the film exhibits peaks corresponding to Si2p (102 eV), O1s (530.6 eV) and W4f (35.1 eV) levels coming from the atoms in the silicontungstate anion. $\mathrm{C} 1 \mathrm{~s}\left(284.5 \mathrm{eV}, \mathrm{sp}^{2}\right.$ hybridization), C12p (197 eV), N1s (399.8 eV, corresponding to organic matrix binding energy) and Ru3d5 (280.5 eV) results from the porphyrin [60,61]. These results reinforce the electrochemical and UV-Vis data already discussed.

The stability of the modified electrodes in aqueous solution was studied evaluating the voltammetric anodic and cathodic peak of the $\mathrm{Ru}^{\mathrm{III} / \mathrm{II}}$ process. For the three bilayers modified electrodes, the current does not decrease in the anodic and cathodic peak over 100 potentiodynamic cycles. The voltammetric profiles of the ME are presented in figure 4 and were obtained in a $0.1 \mathrm{M} \mathrm{NaClO}_{4}$ solution. 
At positive potentials, all ME present a reversible couple attributable to the $\mathrm{Ru}{ }^{\mathrm{III} / \mathrm{II}}$ process of the $\left[\mathrm{Ru}(\text { bipy })_{2} \mathrm{Cl}\right]^{+}$ligand coordinated to the porphyrin. At negative potentials, the voltammogram of $[\mathrm{Mn}(\mathrm{III}) \mathrm{TRP}]^{5+} /\left[\mathrm{SiW}_{12} \mathrm{O}_{40}\right]^{4-} \mathrm{ME}$ exhibit a single process at $-0.5 \mathrm{~V}$, $[\mathrm{Zn}(\mathrm{II}) \mathrm{TRP}]^{4+} /\left[\mathrm{SiW}_{12} \mathrm{O}_{40}\right]^{4-} \mathrm{ME}$ present two processes at $-0.4 \mathrm{~V}$ and $-0.7 \mathrm{~V}$ and $[\mathrm{Ni}(\mathrm{II}) \mathrm{TRP}]^{4+} /\left[\mathrm{SiW}_{12} \mathrm{O}_{40}\right]^{4-} \mathrm{ME}$ present a process at $-0.7 \mathrm{~V}$. These processes mentioned above are describes as reduction processes of the bilayers [43]. The reduced bilayers are reoxidized at positive potentials, where a pre-peak appear before the $\mathrm{Ru}{ }^{\mathrm{III} / \mathrm{II}}$ process [43].

\subsection{Effect of the order in the bilayer formation}

Additionally the effect of the order in the bilayer formation was studied. In this case, a $\left[\mathrm{SiW}_{12} \mathrm{O}_{40}\right]^{4-} /[\mathrm{Zn}(\mathrm{II}) \mathrm{TRP}]^{4+} \mathrm{ME}$ was also prepared with three bilayers. The electrochemical behavior and the morphology of this electrode was compared with the $[\mathrm{Zn}(\mathrm{II}) \mathrm{TRP}]^{4+} /\left[\mathrm{SiW}_{12} \mathrm{O}_{40}\right]^{4-} \mathrm{ME}$.

The cyclic voltammetry of the $\left[\mathrm{SiW}_{12} \mathrm{O}_{40}\right]^{4-} /[\mathrm{Zn}(\mathrm{II}) \mathrm{TRP}]^{4+} \mathrm{ME}$ in a $0.1 \mathrm{M} \mathrm{NaClO}_{4}$ solution is displayed in figure 4 and exhibit at positive potentials, the characteristic $\mathrm{Ru}^{\mathrm{III} / \mathrm{II}}$ process. At negative potentials, it exhibits a single quasireversible process at approximately $-0.5 \mathrm{~V}$ described as a bilayer reduction process [49]. This process seems to be more defined that in the $[\mathrm{Zn}(\mathrm{II}) \mathrm{TRP}]^{4+} /\left[\mathrm{SiW}_{12} \mathrm{O}_{40}\right]^{4-}$ analogous . Probably, due to the nature of this bilayer reduction process that is centered in the porphyrins present in the film, when porphyrins are the external layer in contact with the solution phase there is an increase in electron transfer and supporting electrolyte exchange trough the film. On the other hand, the charge under the $\mathrm{Ru}^{\mathrm{III} / \mathrm{II}}$ process is lower than the charge of the $[\mathrm{Zn}(\mathrm{II}) \mathrm{TRP}]^{4+} /\left[\mathrm{SiW}_{12} \mathrm{O}_{40}\right]^{4-} \mathrm{ME}$. This 
could be due to the amount of electroactive material adsorbed on the ITO surface. In this sense, morphological study was performed by AFM technique.

The images were acquired using tapping mode. Fig. 5a, b and c, shows the 3D AFM images for an ITO electrode, three $[\mathrm{Zn}(\mathrm{II}) \mathrm{TRP}]^{4+} /\left[\mathrm{SiW}_{12} \mathrm{O}_{40}\right]^{4-}$ and three $\left[\mathrm{SiW}_{12} \mathrm{O}_{40}\right]^{4-}$ $/[\mathrm{Zn}(\mathrm{II}) \mathrm{TRP}]^{4+}$ bilayers respectively. For ITO electrode a smooth and homogeneus covered surface is observed. In the case of modified electrodes it is possible to observe a random distribution of aggregates in a pseudo-spherical shape. In Fig. 5b, the AFM image shows larger aggregates, very close to each other, which generates a heterogeneous film with a higher coating zone. In Fig. 5c, it is possible observe aggregates of smaller size. The described contrasts of these images allow us to conclude that the order in the bilayer formation has a direct effect on the surface morphology. It is remarkable that the RMS value obtained for the $[\mathrm{Zn}(\mathrm{II}) \mathrm{TRP}]^{4+} /\left[\mathrm{SiW}_{12} \mathrm{O}_{40}\right]^{4-} \mathrm{ME}$ is 56.2 which is higher than the RMS value for the $\left[\mathrm{SiW}_{12} \mathrm{O}_{40}\right]^{4-} /[\mathrm{Zn}(\mathrm{II}) \mathrm{TRP}]^{4+} \mathrm{ME}$, that is 32.2. A detailed study of height profile demonstrate that $[\mathrm{Zn}(\mathrm{II}) \mathrm{TRP}]^{4+} /\left[\mathrm{SiW}_{12} \mathrm{O}_{40}\right]^{4-} \mathrm{ME}$ have a mean height of $255 \mathrm{~nm}$ and $\left[\mathrm{SiW}_{12} \mathrm{O}_{40}\right]^{4-} /[\mathrm{Zn}(\mathrm{II}) \mathrm{TRP}]^{4+} \mathrm{ME}$ of $178 \mathrm{~nm}$.

These results strengthen the idea of the influence of the external layer in the morphology and the electrochemical properties of the ME.

\subsection{Electrochemical reduction of nitrite}

Figure $6 \mathrm{a}$ presents the I/E curve of a bare ITO electrode and the modified electrodes in presence of $1 \mathrm{mM} \mathrm{NaNO}_{2}$ and $0.1 \mathrm{M} \mathrm{NaClO}_{4}$. For ITO electrode, there is a current increase in approximately $-0.40 \mathrm{~V}$ compared to the voltammetric profile under inert atmosphere, indicating the reduction of nitrite under this experimental conditions. Nitrite reduction at 
$[\mathrm{Mn}(\mathrm{III}) \mathrm{TRP}]^{5+} /\left[\mathrm{SiW}_{12} \mathrm{O}_{40}\right]^{4-},[\mathrm{Zn}(\mathrm{II}) \mathrm{TRP}]^{4+} /\left[\mathrm{SiW}_{12} \mathrm{O}_{40}\right]^{4-}$ and $[\mathrm{Ni}(\mathrm{II}) \mathrm{TRP}]^{4+} /\left[\mathrm{SiW}_{12} \mathrm{O}_{40}\right]^{4-}$ ME takes place at $-0.35,-0.4$ and $-0.65 \mathrm{~V}$ (onset potential) respectively (see Figure $6 \mathrm{~b}, \mathrm{c}$ and d). In the case of $[\mathrm{Mn}(\mathrm{III}) \mathrm{TRP}]^{5+} /\left[\mathrm{SiW}_{12} \mathrm{O}_{40}\right]^{4-}$ and $[\mathrm{Zn}(\mathrm{II}) \mathrm{TRP}]^{4+} /\left[\mathrm{SiW}_{12} \mathrm{O}_{40}\right]^{4-} \mathrm{ME}$, it is observed that the bilayers reduction process (described before) is enhanced by the presence of nitrite. For the $[\mathrm{Ni}(\mathrm{II}) \mathrm{TRP}]^{4+} /\left[\mathrm{SiW}_{12} \mathrm{O}_{40}\right]^{4-}$ the behavior its different, showing that in presence of nitrite, the bilayers reduction process disappear and an increment in the current can be seen at $-0.65 \mathrm{~V}$, however, the results suggest that the reduced bilayers are the active moiety for nitrite reduction.

The current value reached for nitrite reduction, at $-0.8 \mathrm{~V} v \mathrm{Ag} / \mathrm{AgCl}$, presents the following trend: $\quad[\mathrm{Ni}(\mathrm{II}) \mathrm{TRP}]^{4+} /\left[\mathrm{SiW}_{12} \mathrm{O}_{40}\right]^{4-} \quad>\quad[\mathrm{Zn}(\mathrm{II}) \mathrm{TRP}]^{4+} /\left[\mathrm{SiW}_{12} \mathrm{O}_{40}\right]^{4-}>$ $[\mathrm{Mn}(\mathrm{III}) \mathrm{TRP}]^{5+} /\left[\mathrm{SiW}_{12} \mathrm{O}_{40}\right]^{4-}$.

The electrocatalytic activity of the $\left[\mathrm{SiW}_{12} \mathrm{O}_{40}\right]^{4-} /[\mathrm{Zn}(\mathrm{II}) \mathrm{TRP}]^{4+} \mathrm{ME}$ toward nitrite reduction, was tested in the same conditions that the other modified electrodes, where the current values obtained are, in both cases (nitrite presence and absence), smaller than the values reached by all $[\mathrm{M}(\mathrm{II}) \mathrm{TRP}]^{4+} /\left[\mathrm{SiW}_{12} \mathrm{O}_{40}\right]^{4-}$ modified electrodes as expected (see supporting information).

\subsection{Controlled Potential Electrolysis-Reduction Products and Intermediates Detection}

The reduction products for the electrochemical reduction of nitrite at $[\mathrm{MTRP}]^{\mathrm{n}+} /\left[\mathrm{SiW}_{12} \mathrm{O}_{40}\right]^{4-}$ ME, were determined after 6 hours of controlled potential electrolysis at $-0.8 \mathrm{~V}$ vs $\mathrm{Ag} / \mathrm{AgCl}$. Hydroxylamine, hydrazine and ammonia were detected as reaction products, corresponding to a transfer of four, five and six electrons (See eq.(1, 2 and 3)). 


$$
\begin{aligned}
& \mathrm{NO}_{2}^{-}+5 \mathrm{H}^{+}+4 e^{-} \rightarrow \mathrm{NH}_{2} \mathrm{OH}+\mathrm{H}_{2} \mathrm{O} \\
& \mathrm{NO}_{2}^{-}+6 \mathrm{H}^{+}+5 e^{-} \rightarrow \frac{1}{2} \mathrm{~N}_{2} \mathrm{H}_{4}+2 \mathrm{H}_{2} \mathrm{O} \\
& \mathrm{NO}_{2}^{-}+7 \mathrm{H}^{+}+6 e^{-} \rightarrow \mathrm{NH}_{3}+2 \mathrm{H}_{2} \mathrm{O}
\end{aligned}
$$

No other products were detected by the analytical methods used in this work. The electrolysis results are summarized in Table 1. At constant potential, the highest molar concentration of hydroxylamine and hydrazine are obtained with the $[\mathrm{Mn}(\mathrm{III}) \mathrm{TRP}]^{5+} /\left[\mathrm{SiW}_{12} \mathrm{O}_{40}\right]^{4-} \mathrm{ME}$ giving rise to the following trend for different electrodes: $[\mathrm{Mn}(\mathrm{III}) \mathrm{TRP}]^{5+} /\left[\mathrm{SiW}_{12} \mathrm{O}_{40}\right]^{4-}>[\mathrm{Zn}(\mathrm{II}) \mathrm{TRP}]^{4+} /\left[\mathrm{SiW}_{12} \mathrm{O}_{40}\right]^{4-}>[\mathrm{Ni}(\mathrm{II}) \mathrm{TRP}]^{4+} /\left[\mathrm{SiW}_{12} \mathrm{O}_{40}\right]^{4-}>$ ITO blank electrode.

In the case of ammonia, the order it reversed and the higher molar concentration is obtained with the $[\mathrm{Ni}(\mathrm{II}) \mathrm{TRP}]^{4+} /\left[\mathrm{SiW}_{12} \mathrm{O}_{40}\right]^{4-} \quad>\quad[\mathrm{Zn}(\mathrm{II}) \mathrm{TRP}]^{4+} /\left[\mathrm{SiW}_{12} \mathrm{O}_{40}\right]^{4-}>$ $[\mathrm{Mn}(\mathrm{III}) \mathrm{TRP}]^{5+} /\left[\mathrm{SiW}_{12} \mathrm{O}_{40}\right]^{4-}>$ ITO blank electrode.

TOF (turn over frequency) [5,43], TON (turn over number) $[43,62,63]$ and faradaic efficiency values were obtained from controlled potential experiments, and they are summarized in Table 1. The first two values are indicators of the real catalytic activity of each ME. For all cases, the trend is the same that those observed for total amount of reaction product obtained. Whereas faradaic efficiency indicates that the distribution of obtained products is favorable for $\mathrm{N}$ protonated species, while gaseous products must be in low level of production

Finally, in the case of the $\left[\mathrm{SiW}_{12} \mathrm{O}_{40}\right]^{4-} /[\mathrm{Zn}(\mathrm{II}) \mathrm{TRP}]^{4+} \mathrm{ME}$, only hydrazine and ammonia could be detected as reduction product. The molar concentration of product and the TOF 
and TON values are well below of the values for the other ME. Thus, no further experiments were performed with this electrode.

Compared to other modified electrodes with coordination compounds was found that TOF calculated values are low $[5,29,64]$. However, when comparing the concentration levels of the products obtained, these values are in the same order of magnitude. Even, the present electrodes are able to generate highly hydrogenated products (ammonia) that with other systems can not be obtained [64].

\subsection{IR spectroelectrochemical experiments}

One pertinent question is related with the change in the activity/selectivity of the modified electrodes and the influence of central metal ion coordinated in the cavity of the macrocycle, thus in order to acquire molecular insights about the coordination properties of the macrocycle, as a previous path to electron transfer and products release, IR spectroelectrochemical experiments were carried out for complexes used in this work.

Figures 7 displays the IR spectroelectrochemical results of $[\mathrm{MTRP}]^{\mathrm{n}+}$ in presence and absence of nitrite. In the case of $[\mathrm{Mn}(\mathrm{III}) \mathrm{TRP}]^{5+}$ (figure $7 \mathrm{a}$ ) in absence of nitrite, at open circuit potential, a set of bands can be observed at the region of $1400-1500 \mathrm{~cm}^{-1}$ corresponding to the double bonds vibrational modes [65] of the porphyrin ring. As negative potential is applied, the band at $1446 \mathrm{~cm}^{-1}$ decreases its intensity according with the reduction of the macrocyclic ligand. While the others in 1422 and 1466 slightly increased its intensity. However is presence of nitrite (figure 7b), at open circuit potential only one set of bands is observed where vibrations at $1422 \mathrm{~cm}^{-1}$ and $1466 \mathrm{~cm}^{-1}$ are detected. 
As negative potential is applied a new vibration at $1444 \mathrm{~cm}^{-1}$ is observed, this band evidence the formation of a Mn-ONO species that is consistent with the work of Suslick et $a l$, where tetra-phenyl-porphyrins of Mn-nitrito (Mn-O-N-O bound) species where prepared and characterized [66]. On the other hand, for $[\mathrm{Zn}(\mathrm{II}) \mathrm{TRP}]^{4+}$ (Figure $7 \mathrm{c}$ ) in absence of nitrite, its spectroelectrochemical behavior, at open circuit potential, is similar to that found for $[\mathrm{Mn}(\mathrm{III}) \mathrm{TRP}]^{5+}$ complex, however in presence on nitrite ion and negative potential applied (figure 7d) a broad band is observed without resolution indicating the lack of specific interactions.

\subsection{Photoelectrochemical Reduction of nitrite}

These modified electrodes undergo multiple electronic transitions in the range of visible light. This property can be combined with the electrocatalytic behavior showed for nitrite reduction, giving rise to a synergistic effect between polarization, over potential and light excitation.

Figure 8a present the I/E curve for an ITO in presence of nitrite in darkness and under light irradiation. For the ITO electrode, it can be seen that under light irradiation the current associated to nitrite reduction increased, evidencing a photoelectrochemical effect associated with the semiconductor properties of this substrate. On the other hand, for the ME (Figure 8b, c and d) the combination of light and potential give rise to an increase in the current associated with nitrite reduction. In comparison with their behavior in dark conditions, at the same potential $(-0.80 \mathrm{~V}$ vs $\mathrm{Ag} / \mathrm{AgCl}),[\mathrm{Mn}(\mathrm{III}) \mathrm{TRP}]^{5+} /\left[\mathrm{SiW}_{12} \mathrm{O}_{40}\right]^{4-}$, $[\mathrm{Zn}(\mathrm{II}) \mathrm{TRP}]^{4+} /\left[\mathrm{SiW}_{12} \mathrm{O}_{40}\right]^{4-}$ and $[\mathrm{Ni}(\mathrm{II}) \mathrm{TRP}] /\left[\mathrm{SiW}_{12} \mathrm{O}_{40}\right]^{4-} \mathrm{ME}$, exhibit a current increase of

\section{5, 2.8 and 1.3 times respectively.}


For the $[\mathrm{Zn}(\mathrm{II}) \mathrm{TRP}]^{4+} /\left[\mathrm{SiW}_{12} \mathrm{O}_{40}\right]^{4-} \mathrm{ME}$, there is a current increase on the nitrite reduction process at $-0.40 \mathrm{~V}(\mathrm{vs} \mathrm{Ag} / \mathrm{AgCl})$ described in dark conditions. It is also visible the appearance of a new reduction process at approximately $-0.70 \mathrm{~V}(\mathrm{vs} \mathrm{Ag} / \mathrm{AgCl})$ that can be attributable to the reduction of an adsorbed species. In the case of the $[\mathrm{Ni}(\mathrm{II}) \mathrm{TRP}]^{4+} /\left[\mathrm{SiW}_{12} \mathrm{O}_{40}\right]^{4-}$ there is no significant difference in the shape of the linear voltammogram in dark conditions, but there is a current increase, as it was described above.

Particularly, it can be notice that for the $[\mathrm{Mn}(\mathrm{III}) \mathrm{TRP}]^{5+} /\left[\mathrm{SiW}_{12} \mathrm{O}_{40}\right]^{4-} \mathrm{ME}$, in dark conditions, presents a single irreversible process $(-0.6 \mathrm{~V})$ (see figure 6). Under light irradiation $[\mathrm{Mn}(\mathrm{III}) \mathrm{TRP}]^{5+} /\left[\mathrm{SiW}_{12} \mathrm{O}_{40}\right]^{4-} \mathrm{ME}$ present an onset potential $300 \mathrm{mV}$ more negative for the nitrite reduction process, however, there is a significant current enhancement.

\subsection{Potential controlled electrolysis and detection of intermediaries}

Potential controlled electrolysis experiments were performed at $-0.65 \mathrm{~V}$ (vs $\mathrm{Ag} / \mathrm{AgCl}$ ) for three hours. These conditions are $150 \mathrm{mV}$ less negative and half of the time than the experiments in dark conditions and were carried out to highlight the activity under irradiation. The obtained reaction products were hydrazine and ammonia, showing that potential and light combination promotes the transfer of 5 and 6 electrons to nitrite. The results are summarized in table 2 .

As it can be seen, the biggest amount of hydrazine produced under light irradiation was obtained with the $[\mathrm{Zn}(\mathrm{II}) \mathrm{TRP}]^{4+} /\left[\mathrm{SiW}_{12} \mathrm{O}_{40}\right]^{4-} \mathrm{ME}$ followed by $[\mathrm{Mn}(\mathrm{III}) \mathrm{TR}]^{5+} /\left[\mathrm{SiW}_{12} \mathrm{O}_{40}\right]^{4-}$, $[\mathrm{Ni}(\mathrm{II}) \mathrm{TRP}]^{4+} /\left[\mathrm{SiW}_{12} \mathrm{O}_{40}\right]^{4-}$ and finally the bare ITO electrode. 
Compared to the results obtained in dark conditions, $[\mathrm{Mn}(\mathrm{III}) \mathrm{TRP}]^{5+} /\left[\mathrm{SiW}_{12} \mathrm{O}_{40}\right]^{4-} \mathrm{ME}$ increase its hydrazine production only 3 times, whereas $[\mathrm{Zn}(\mathrm{II}) \mathrm{TRP}]^{4+} /\left[\mathrm{SiW}_{12} \mathrm{O}_{40}\right]^{4-}$ and $[\mathrm{Ni}(\mathrm{II}) \mathrm{TRP}]^{4+} /\left[\mathrm{SiW}_{12} \mathrm{O}_{40}\right]^{4-} \mathrm{ME}$, in about 6 and 5 times respectively. This result is also evidenced in the increase of 1-2 order of magnitude for the TOF values and in the increase in 4 orders of magnitude for the TON values (see table 2).

In the case of ammonia, $[\mathrm{Mn}(\mathrm{III}) \mathrm{TRP}]^{5+} /\left[\mathrm{SiW}_{12} \mathrm{O}_{40}\right]^{4-}$ MME produces the biggest amount followed by $[\mathrm{Zn}(\mathrm{II}) \mathrm{TRP}]^{4+} /\left[\mathrm{SiW}_{12} \mathrm{O}_{40}\right]^{4-}>[\mathrm{Ni}(\mathrm{II}) \mathrm{TRP}]^{4+} /\left[\mathrm{SiW}_{12} \mathrm{O}_{40}\right]^{4-}>$ bare ITO electrode. Compared to dark conditions, ammonia production increases twice with the $[\mathrm{Mn}(\mathrm{III}) \mathrm{TRP}]^{5+} /\left[\mathrm{SiW}_{12} \mathrm{O}_{40}\right]^{4-} \mathrm{ME}, 1.4$ times with the $[\mathrm{Zn}(\mathrm{II}) \mathrm{TRP}]^{4+} /\left[\mathrm{SiW}_{12} \mathrm{O}_{40}\right]^{4-} \mathrm{ME}$ and

once for $[\mathrm{Ni}(\mathrm{II}) \mathrm{TRP}]^{4+} /\left[\mathrm{SiW}_{12} \mathrm{O}_{40}\right]^{4-}$ ME. TOF values also increase in 1 order of magnitude and TON increase in 3 orders of magnitude, following the same trend.

The sum of the obtained values for faradaic efficiency (nearly 90\%) show that the effect of the combination of light and potential generates highly protonated products and the generation of gaseous products is low.

The described results, agree with the hypothesis of a synergic behavior by the integration of photocatalysis and electrocatalysis, leading to an improve in the electrocatalytic behavior of the modified electrodes, were the applied potential facilitates the separation of photoinduced carriers while light absorption lowers the energetic barrier promoting the electron transfer $[43,67]$.

\subsection{Photolysis experiments}

Figure 9 shows photolysis results of nitrite reduction in a $[\mathrm{MTRP}]^{\mathrm{n}+}(\mathrm{M}=\mathrm{Mn}(\mathrm{III}), \mathrm{Zn}(\mathrm{II})$ and $\mathrm{Ni}(\mathrm{II})$ ) solution. In the case of $[\mathrm{Ni}(\mathrm{II}) \mathrm{TRP}]^{4+}$ (figure $9 \mathrm{c}$ ), in absence of TBAN, two 
isosbestic points appear at 366 and $506 \mathrm{~nm}$, evidencing an equilibrium between the reduced species $[\mathrm{Ni}(\mathrm{II}) \mathrm{TRP}]^{4+} \cdot$ and the and the oxidized one $[\mathrm{Ni}(\mathrm{II}) \mathrm{TRP}]^{4+}$. As there is no change in the Soret band in presence of TBAN (see figure 9d), it can establish that the reduced species is the porphyrin radical form (Eqs 4-6) [40].

For the $[\mathrm{Zn}(\mathrm{II}) \mathrm{TRP}]^{4+}$ (not shown), in absence or presence of TBAN, the behavior is similar to $[\mathrm{Ni}(\mathrm{II}) \mathrm{TRP}]^{4+}$.

On the other hand the $[\mathrm{Mn}(\mathrm{III}) \mathrm{TRP}]^{5+}$ experiments in absence of TBAN exhibit a similar behavior in comparison with $[\mathrm{Ni}(\mathrm{II}) \mathrm{TRP}]^{4+}$ and $[\mathrm{Zn}(\mathrm{II}) \mathrm{TRP}]^{4+}$ (see figure 9a). However, a different behavior can be notice in the presence of TBAN, were a new Soret band at 430nm arises with the consecutive irradiation (figure $9 b$ ). This is a proof of the reduction of the metal center in the porphyrin, from $\mathrm{Mn}^{\mathrm{III}}$ to $\mathrm{Mn}^{\mathrm{II}}$ (Eq 7) [40] giving rise to the formation of an $\left[\mathrm{Mn}(\mathrm{II}) \mathrm{TRP}-\mathrm{NO}_{2}\right]$ species. It has been demonstrated that $\mathrm{Mn}$ Mioglobine [Mn(II)Mb] may form complexes with nitrite $\left[\mathrm{Mn}^{\mathrm{II}} \mathrm{Mb}-\mathrm{NO}_{2}\right]$ species [19], analogue to the [Mn(II)TRP$\mathrm{NO}_{2}$ ] observed in this work. This could explain the difference noted in the electrocatalytic response of $[\mathrm{Mn}(\mathrm{III}) \mathrm{TRP}]^{5+} /\left[\mathrm{SiW}_{12} \mathrm{O}_{40}\right]^{4-} \mathrm{ME}$ under light irradiation, where compared to the behavior in dark conditions (see Figure 8), the reduction potential was higher. In this case, nitrite reduction involves a higher kinetic barrier due to the stable complex formed but, at the same time, this complex give rise to the formation of higher reduced product, evidenced in the increase of ammonia production for this ME.

$$
\begin{aligned}
& {[Z n(I I) T R P]^{+4}+h v \leftrightarrows[\operatorname{Zn}(I I) T R P]^{+4}} \\
& {[N i(I I) T R P]^{+4}+h v \leftrightarrows[N i(I I) T R P]^{+4}} \\
& {[M n(I I I) T R P]^{+5}+h v \leftrightarrows[M n(I I I) T R P]^{+5}}
\end{aligned}
$$




$$
[\mathrm{Mn}(\mathrm{III}) \mathrm{TRP}]^{+5 \bullet}+\mathrm{NO}_{2}^{-} \leftrightarrows\left[\mathrm{Mn}(\mathrm{II}) \mathrm{TRP}-\mathrm{NO}_{2}\right]^{+3}
$$

Consequently based in the presence of experimental data and related literature a probable mechanism can be suggested (See scheme 1).

\section{CONCLUSION}

Electrochemical measurements demonstrated that it was possible to adsorb three $[\mathrm{MTRP}]^{\mathrm{n}+} /\left[\mathrm{SiW}_{12} \mathrm{O}_{40}\right]^{4-}$ bilayers onto the ITO surface giving rise to three types of stable modified electrodes (ME). Electrochemical and morphological results shown that when the bilayer are formed adsorbing first the porphyrin and secondly $\left[\mathrm{SiW}_{12} \mathrm{O}_{40}\right]^{4-}$, the amount of electroactive material adsorbed was higher. All ME used in this work, exhibit electrocatalytic behavior for nitrite reduction in aqueous media, giving rise to the formation of hydroxylamine, hydrazine and ammonia. Combination of light and potential generates a synergistic effect where all ME improve their electrocatalytic activity changing the selectivity and increasing the amount of reaction product.

Particularly, $[\mathrm{Mn}(\mathrm{III}) \mathrm{TRP}]^{5+} /\left[\mathrm{SiW}_{12} \mathrm{O}_{40}\right]^{4-} \mathrm{ME}$, in dark conditions exhibit the lower onset potential for Nitrite reduction with less favored ammonia production. Under irradiated conditions the onset potential for nitrite reduction is the more negative of the complex series studied, however, its behavior for ammonia production is highly enhanced. IR 
spectroelectrochemical and photolysis experiments probe that $[\mathrm{Mn}(\mathrm{III}) \mathrm{TRP}]^{5+}$ form a complex with nitrite which in photoelectrochemical conditions is highly reactive.

\section{AUTHOR INFORMATION}

Corresponding author Dr. Mauricio Isaacs C.misaacs@uc.cl

\section{ACKNOWLEDGEMENTS}

Authors acknowledge the financial support of FONDECYT, project \#1141199 and RC 130006, CILIS, granted by Fondo de Innovación para la Competitividad del Ministerio de Economía, Fomento y Turismo, Chile. M.G. acknowledges Postdoctoral FONDECYT project \# 3140085. J.H., D.Q. and C.D acknowledge the CONICYT scholarships for Ph. D. studies in Chile. P.D. acknowledges financial support of FONDECYT, project \# 11130221 and the USM-Project \# 131439. F.C. acknowledges Postdoctoral FONDECYT project \# 3150222. G.C. and C.P.K. acknowledge support from the NSF CHE-1145893. M. J. A. acknowledges the financial support of FONDECYT, project \#1120071. F.G. acknowledgment Postdoctoral Fondecyt Project \# 3140565 . 


\section{REFERENCES}

[1] W.J.R. Santos, P.R. Lima, A. a. Tanaka, S.M.C.N. Tanaka, L.T. Kubota, Determination of nitrite in food samples by anodic voltammetry using a modified electrode, Food Chem. 113 (2009) 1206-1211.

[2] A. Guzmán-Vargas, M. a. Oliver-Tolentino, E. Lima, J. Flores-Moreno, Efficient electrocatalytic reduction of nitrite species on zeolite modified electrode with $\mathrm{Cu}$ ZSM-5, Electrochim. Acta. 108 (2013) 583-590.

[3] K. Nakata, Y. Doi, S. Kubota, K. Shimazu, Reduction of nitrite on tin-modified noble metal electrodes, J. Electroanal. Chem. 647 (2010) 187-193.

[4] P. Swann, The Toxicology of Nitrate, Nitrite and N-Nitroso Compounds, J. Sci. Food Agric. 26 (1975) 1761-1770.

[5] P. Dreyse, M. Isaacs, K. Calfumán, C. Cáceres, A. Aliaga, M.J. Aguirre, et al., Electrochemical reduction of nitrite at poly-[Ru(5-NO2-phen)2Cl] tetrapyridylporphyrin glassy carbon modified electrode, Electrochim. Acta. 56 (2011) 5230-5237.

[6] M. Fan, V.E. Steinberg, Health implications of nitrate and nitrite in drinking water: an update on methemoglobinemia occurrence and reproductive and developmental toxicity., Regul. Toxicol. Pharmacol. 23 (1996) 35-43.

[7] L. Airoldi, A. Galli, F. Mercato, F. Vago, R. Fanelli, E. Negri, et al., Salivary nitrate, nitrite and N-nitroso compounds in patients with cancer of the upper aerodigestive tract, Eur. J. Cancer Prev. 6 (1997) 351-356.

[8] H. Zhang, S. Qi, Y. Dong, X. Chen, Y. Xu, Y. Ma, et al., A sensitive colorimetric method for the determination of nitrite in water supplies, meat and dairy products using ionic liquid-modified methyl red as a colour reagent., Food Chem. 151 (2014) 429-34.

[9] G.. Greenway, S.. Haswell, P.. Petsul, Characterisation of a micro-total analytical system for the determination of nitrite with spectrophotometric detection, Anal. Chim. Acta. 387 (1999) 1-10.

[10] M.I.H. Helaleh, T. Korenaga, Ion Chromatographic method for simultaneous determination of nitrate and nitrite in human saliva, J. Chromatogr. b. 744 (2000) 433-437.

[11] L. He, K. Zhang, C. Wang, X. Luo, S. Zhang, Effective indirect enrichment and determination of nitrite ion in water and biological samples using ionic liquiddispersive liquid-liquid microextraction combined with high-performance liquid chromatography., J. Chromatogr. A. 1218 (2011) 3595-600. 
[12] J. Zheng, T. Lu, T.M. Cotton, G. Chumanov, Photoinduced Electrochemical Reduction of Nitrite at an Electrochemically Roughened Silver Surface, J. Phys. Chem. B. 103 (1999) 6567-6572.

[13] D. De, J.D. Englehardt, E.E. Kalu, Electroreduction of Nitrate and Nitrite Ion on a Platinum- Group - Metal Catalyst- Modified Carbon Fiber Electrode Chronoamperometry and Mechanism Studies, J. Electrochem. Soc. . 147 (2000) 4573-4579.

[14] M.. de Groot, M.T.. Koper, The influence of nitrate concentration and acidity on the electrocatalytic reduction of nitrate on platinum, J. Electroanal. Chem. 562 (2004) 81-94.

[15] W. Sun, S. Zhang, X. Lin, L. Jin, S. Jin, J. Deng, Electrocatalytic reduction of nitrite at a carbon fiber microelectrode chemically modified by palladium ( II ) -substituted Dawson type heptadecatungstodiphosphate, J. Electroanal. Chem. 469 (1999) 63-71.

[16] S. Sunohara, K. Nishimura, Y. Takasu, R. Ohnishi, M. Ueno, K. Yahikozawa, Reply to the comment by S. Wasmus and W. Vielstich on the paper entitled on-line mass spectroscopic observation of the reduction and oxidation of NO2 on graphitesupported copper oxide electrodes in aqueous media, J. Electroanal. Chem. 374 (1994) 247-249.

[17] S. Sunohara, K. Nishimura, K. Yahikozawa, M. Ueno, Electrocatalysis of transitionmetal oxides for reduction and oxidation of nitrite ions, J. Electroanal. Chem. 354 (1993) 161-171.

[18] S. Sunohara, K. Nishimura, R. Ohnishi, M. Enyo, M. Ueno, K. Yahikozawa, et al., On-line mass spectroscopic observation of the reduction and oxidation of $\mathrm{NO} 2-$ on graphite-supported copper oxide electrodes in aqueous media, J. Electroanal. Chem. 353 (1993) 297-301.

[19] J.L. Heinecke, J. Yi, J.C.M. Pereira, G.B. Richter-Addo, P.C. Ford, Nitrite reduction by $\mathrm{Co}(\mathrm{II})$ and $\mathrm{Mn}(\mathrm{II})$ substituted myoglobins: towards understanding necessary components of Mb nitrite reductase activity., J. Inorg. Biochem. 107 (2012) 47-53.

[20] K. Calfumán, M.J. Aguirre, P. Cañete-Rosales, S. Bollo, R. Llusar, M. Isaacs, Electrocatalytic reduction of nitrite on tetraruthenated metalloporphyrins/Nafion glassy carbon modified electrode, Electrochim. Acta. 56 (2011) 8484-8491.

[21] M.H. Barley, T.J. Meyer, Electrocatalytic reduction of nitrite to ammonia based on a water-soluble iron porphyrin., J. Am. Chem. Soc. 108 (1986) 5876-85.

[22] M. Barley, M. Rhodes, T. Meyer, Electrocatalytic reduction of nitrite to nitrous oxide and ammonia based on the N-methylated, cationic iron porphyrin complex 5+, Inorg. Chem. 26 (1987) 1746-1750. 
[23] J. Younathan, K. Wood, T. Meyer, Electrocatalytic reduction of nitrite and nitrosyl by iron (III) protoporphyrin IX dimethyl ester immobilized in an electropolymerized film, Inorg. Chem. 31 (1992) 3280-3285.

[24] M. Rhodes, T. Meyer, Electrocatalytic reduction of nitrite using simple coordination complexes of iron and ruthenium, Inorg. Chem. 02 (1988) 4112-4114.

[25] J. Hayon, a. Raveh, a. Bettelheim, Electrocatalytic properties of chemically polymerized films of cobalt, iron and manganese tetrakis(o-aminophenyl)porphyrins, J. Electroanal. Chem. 359 (1993) 209-221.

[26] C.A. Caro, F. Bedioui, M.A. Páez, G.I. Cárdenas-Jiron, J.H. Zagal, Experimental and theoretical study of the activity of substituted metallophthalocyanines for nitrite electro-oxidation, J. Electrochem. Soc. 151 (2004) 332-339.

[27] F. Roncaroli, R. van Eldik, Mechanistic analysis of reductive nitrosylation on watersoluble cobalt(III)-porphyrins., J. Am. Chem. Soc. 128 (2006) 8042-53.

[28] L. Taniguchi, N. Nakashima, K. Yasukouchi, Reduction of nitrate to give hydroxylamine at a mercury electrode using cobalt(III)-and nickel(II)-cyclams as catalysts, J. Chem. Soc. Chem. Commun. (1986) 1814-1815.

[29] O. Winther-jensen, B. Winther-jensen, Electrochemistry Communications Reduction of nitrite to ammonia on PEDOT - bipyridinium - Fe complex electrodes, Electrochem. Commun. 43 (2014) 98-101.

[30] J. Rhule, C. Hill, D. Judd, R. Schinazi, Polyoxometalates in Medicine., Chem. Rev. 98 (1998) 327.

[31] D. Long, E. Burkholder, L. Cronin, Polyoxometalate clusters, nanostructures and materials: from self assembly to designer materials and devices., Chem. Soc. Rev. 36 (2007) 105.

[32] Y. Shen, J. Liu, J. Jiang, Fabrication of a metalloporphyrin-polyoxometalate hybrid film by a layer-by-layer method and its catalysis for hydrogen evolution and dioxygen reduction, J. Phys. Chem. B. 107 (2003) 9744.

[33] S. Dong, X. Xi, M. Tian, Study of the electrocatalytic reduction of nitrite with silicotungstic heteropolyanion, J. Electroanal. Chem. 385 (1995) 227.

[34] K. Wiaderek, J. Cox, Preparation and Electrocatalytic Application of Composites Containing Gold Nanoparticles Protected with Rhodium-Substituted Polyoxometalates., Electrochim. Acta. 56 (2011) 3537-3542. 
[35] D. Fernandes, C. Brett, A. Cavaleiro, Layer-by-layer self-assembly and electrocatalytic properties of poly(ethylenimine)-silicotungstate multilayer composite films, J. Solid State Electrochem. 15 (2010) 811.

[36] W. Liu, W. Mu, M. Liu, X. Zhang, H. Cai, Y. Deng, Solar-induced direct biomassto-electricity hybrid fuel cell using polyoxometalates as photocatalyst and charge carrier., Nat. Commun. 5 (2014) 3208.

[37] K. Araki, H.E. Toma, Sinthesis and characterization of a multibridged porphyrin complex containing peripheral bis (bipyridine) -ruthenium (II) groups, Jounal Coord. Chem. 30 (1993) 9-17.

[38] K. Araki, M. Wagner, M. Wrighton, Layer-by-Layer Growth of Electrostatically Assembled Multilayer Porphyrin Films, Langmuir. 12 (1996) 5393.

[39] K. Calfumán, M. Aguirre, D. Villagra, Nafion/tetraruthenated porphyrin glassy carbon-modified electrode: characterization and voltammetric studies of sulfite oxidation in water-ethanol solutions, J. Solid State .... 14 (2010) 1065.

[40] H.E. Toma, K. Araki, Supramolecular assemblies of ruthenium complexes and porphyrins, Coord. Chem. Rev. 196 (2000) 307-329.

[41] I. Mayer, H. Toma, K. Araki, Electrocatalysis on tetraruthenated nickel and cobalt porphyrins electrostatic assembled films, J. Electroanal. Chem. 590 (2006) 111.

[42] I. Mayer, H. Toma, K. Araki, Multielectronic redox and electrocatalytic supramolecular films based on a tetraruthenated iron porphyrin, Electrochim. Acta. 52 (2006) 263.

[43] M. García, M.J. Aguirre, G. Canzi, C.P. Kubiak, M. Ohlbaum, M. Isaacs, Electro and photoelectrochemical reduction of carbon dioxide on multimetallic porphyrins/polyoxotungstate modified electrodes, Electrochim. Acta. 115 (2014) $146-154$.

[44] S.P. Sullivan, D.J. Salmon, T.. Meyer, Mixed Phosphine 2,2'-Bipirydine Complexes of Ruthenium, Inorg. Chem. 17 (1978) 3334-3341.

[45] I. Mayer, M. Nakamura, H.E. Toma, K. Araki, Multielectronic redox and electrocatalytic supramolecular films based on a tetraruthenated iron porphyrin, Electrochim. Acta. 52 (2006) 263-271.

[46] I. Mayer, H.E. Toma, K. Araki, Electrocatalysis on tetraruthenated nickel and cobalt porphyrins electrostatic assembled films, J. Electroanal. Chem. 590 (2006) 111-119.

[47] K. Araki, L. Angnes, H.E. Toma, Rectifying Properties and Photoconductivity of Tetraruthenated Nickel Porphyrin Films, Adv. Mater. 7 (1995) 554-559. 
[48] K. Araki, H.E. Toma, Luminescence, spectroelectrochemistry and photoelectrochemical properties of a tetraruthenated zinc porphyrin, J. Photochem. Photobiol. A Chem. 83 (1994) 245-250.

[49] M. García, K. Carfumán, C. Díaz, C. Garrido, I. Osorio-Román, M.J. Aguirre, et al., Multimetallic porphyrins/polyoxotungstate modified electrodes by layer-by-layer method: Electrochemical, spectroscopic and morphological characterization, Electrochim. Acta. 80 (2012) 390-398.

[50] D. Caldiz, L. Lanfrancon, Aplicación de hidrazida maleica en papa (Solanum tuberosum L cv. Spunta) y sus efectos sobre el rendimiento, la brotación y el nivel de residuos en los, Rev. Latinoam. La Papa La Papa. 11 (1999) 164-172.

[51] A. Afkhami, T. Madrakian, A. Maleki, Indirect kinetic spectrophotometric determination of hydroxylamine based on its reaction with iodate., Anal. Sci. 22 (2006) 329-31.

[52] L.S. Clesceri, A.E. Greenberg, A.D. Eaton, Standar Methods for the examination of water and wastewater, 21st ed., American Public Health Association, 2005.

[53] I. Zavarine, C. Kubiak, A versatile variable temperature thin layer reflectance spectroelectrochemical cell, J. Electroanal. Chem. 495 (2001) 106-109.

[54] J.M. Smieja, C.P. Kubiak, Re(bipy-tBu)(CO)3Cl-improved catalytic activity for reduction of carbon dioxide: IR-spectroelectrochemical and mechanistic studies., Inorg. Chem. 49 (2010) 9283-9.

[55] K. Nomiya, M. Miwa, Structural stability index of heteropoly-and isopoly-anions, Polyhedron. 3 (1984) 341-346.

[56] A. Kobayashi, Y. Sasaki, The Crystal Structure of $\alpha$-Barium 12-Tungstosilicate, $\alpha$ Ba 2 SiW 12 O 40·16H 2 O, Bull. Chem. Soc. Jpn. 48 (1975) 885-888.

[57] M. Sadakane, E. Steckhan, Electrochemical Properties of Polyoxometalates as Electrocatalysts., Chem. Rev. 98 (1998) 219-238.

[58] K. Araki, H.. Toma, N4-Macrocyclic Metal Complexes: supramolecular porphyrins as electrocatalysts, New York, 2006.

[59] G. Bazzan, W. Smith, L.C. Francesconi, C.M. Drain, Electrostatic self-organization of robust porphyrin-polyoxometalate films., Langmuir. 24 (2008) 3244-9.

[60] I. Ahmed, R. Farha, Z. Huo, C. Allain, X. Wang, H. Xu, et al., Porphyrinpolyoxometalate hybrids connected via a Tris-alkoxo linker for the generation of photocurrent, Electrochim. Acta. 110 (2013) 726-734. 
[61] A. Kaplan, E. Korin, A. Bettelheim, Structures Self-Assembled from Anionic Graphene and Cationic Manganese Porphyrin: Characterization and Application in Artificial Photosynthesis, Eur. J. Inorg. Chem. 2014 (2014) 2288-2295.

[62] D.K. Dutta, J.D. Woollins, A.M.Z. Slawin, A.L. Fuller, B. Deb, P.P. Sarmah, et al., Rhodium(I) carbonyl complexes of chalcogen functionalized tripodal phosphines, $[\mathrm{CH} 3 \mathrm{C}(\mathrm{CH} 2 \mathrm{P}(\mathrm{X}) \mathrm{Ph} 2) 3]\{\mathrm{X}=\mathrm{O}, \mathrm{S}, \mathrm{Se}\}$ and their reactivity, J. Mol. Catal. A Chem. 313 (2009) 100-106.

[63] Y. Hayashi, N. Komiya, K. Suzuki, S.-I. Murahashi, Copper-catalyzed aerobic oxidative functionalization of $\mathrm{C}-\mathrm{H}$ bonds of alkanes in the presence of acetaldehyde under mild conditions, Tetrahedron Lett. 54 (2013) 2706-2709.

[64] C. Cáceres, M. Martínez, C. Rodríguez, P. Dreyse, V. Ortega, M. Isaacs, Electrochemical coating of [trans-L14CoIIICNFeII(CN)5]Na on ITO/Au electrode and its electrocatalytic properties towards nitrite reduction, J. Electroanal. Chem. 722-723 (2014) 1-6.

[65] J.O. Alben, S.S. Choi, A.D. Adler, W.S. Caughey, INFRARED SPECTROSCOPY OF PORPHYRINS*, Ann. N. Y. Acad. Sci. 206 (1973) 278-295.

[66] K.S. Suslick, R. a. Watson, Photochemical reduction of nitrate and nitrite by manganese and iron porphyrins, Inorg. Chem. 30 (1991) 912-919.

[67] J. Zhao, X. Wang, Z. Xu, J.S.C. Loo, Hybrid catalysts for photoelectrochemical reduction of carbon dioxide: a prospective review on semiconductor/metal complex co-catalyst systems, J. Mater. Chem. A. 2 (2014) 15228-15233. 


\section{FIGURE CAPTIONS}

Figure 1: a) Structure of a $\mu$-(meso-5,10,15,20 tetra(pirydil)porphyrin) $\{$ bis(bipyridine)chloride ruthenium(II) $\}$ b) structure of polyoxotungstate anion.

Figure 2: a) Relation between Ipa of $\mathrm{Ru}$ III/II process of the porphyrin and the number of bilayers. b) Relation between Abs at the Soret band and the number of bilayers.

Figure 3: XPS spectrum of $[\mathrm{Mn}(\mathrm{III}) \mathrm{TRP}]^{5+} /\left[\mathrm{SiW}_{12} \mathrm{O}_{40}\right]^{4-}$ bilayer on ITO electrode.

Figure 4: Voltammetric profile of $[\mathrm{Mn}(\mathrm{III}) \mathrm{TRP}]^{5+} /\left[\mathrm{SiW}_{12} \mathrm{O}_{40}\right]^{4-}, \quad[\mathrm{Ni}(\mathrm{II}) \mathrm{TRP}]^{4+} /\left[\mathrm{SiW}_{12} \mathrm{O}_{40}\right]^{4-}$, $[\mathrm{Zn}(\mathrm{III}) \mathrm{TRP}]^{4+} /\left[\mathrm{SiW}_{12} \mathrm{O}_{40}\right]^{4-}$ and $\left[\mathrm{SiW}_{12} \mathrm{O}_{40}\right]^{4-} /[\mathrm{Zn}(\mathrm{III}) \mathrm{TRP}]^{4+}$ modified electrode a) Cathodic zone, b) anodic zone. $0.1 \mathrm{M} \mathrm{NaClO}_{4}$ solution at $100 \mathrm{mVs}^{-1}$. Potentials are versus $\mathrm{Ag} / \mathrm{AgCl}$.

Figure 5: 3D AFM images of a) ITO electrode b) modified electrode surface with 3 $[\mathrm{Zn}(\mathrm{II}) \mathrm{TRP}]^{4+} /\left[\mathrm{SiW}_{12} \mathrm{O}_{40}\right]^{4-}$ bilayers and c) $3\left[\mathrm{SiW}_{12} \mathrm{O}_{40}\right]^{4-} /[\mathrm{Zn}(\mathrm{II}) \mathrm{TRP}]^{4+}$ bilayer

Figure 6: Linear sweep voltammogram of a) bare ITO electrode b) $[\mathrm{Mn}(\mathrm{III}) \mathrm{TRP}]^{5+} /\left[\mathrm{SiW}_{12} \mathrm{O}_{40}\right]^{4-}$ modified electrode c) $[\mathrm{Zn}(\mathrm{III}) \mathrm{TRP}]^{4+} /\left[\mathrm{SiW}_{12} \mathrm{O}_{40}\right]^{4-}$ modified electrode and d) $[\mathrm{Ni}(\mathrm{II}) \mathrm{TRP}]^{4+} /\left[\mathrm{SiW}_{12} \mathrm{O}_{40}\right]^{4-}$ modified electrode in presence (solid line) and absence (dash line) of $1 \mathrm{mM} \mathrm{NaNO}_{2}, 0.1 \mathrm{M} \mathrm{NaClO}_{4}$ solution, $\mathrm{pH} 5.7$, at $5 \mathrm{mVs}^{-1}$. Potentials are versus $\mathrm{Ag} / \mathrm{AgCl}$. 
Figure 7: IR spectroelectrochemical results of a) $[\mathrm{Mn}(\mathrm{III}) \mathrm{TRP}]^{5+}$ in absence of TBAN b) $[\mathrm{Mn}(\mathrm{III}) \mathrm{TRP}]^{5+}$ in presence of $\mathrm{TBAN}$ c) $[\mathrm{Zn}(\mathrm{II}) \mathrm{TRP}]^{4+}$ in absence of TBAN and d) $[\mathrm{Zn}(\mathrm{II}) \mathrm{TRP}]^{4+}$ in presence of TBAN. Deuterated acetonitrile as solvent, TBAH as support electrolyte.

Figure 8: Linear sweep voltammogram of a) bare ITO electrode b) $[\mathrm{Mn}(\mathrm{III}) \mathrm{TRP}]^{5+} /\left[\mathrm{SiW}_{12} \mathrm{O}_{40}\right]^{4-}$ modified electrode c) $[\mathrm{Zn}(\mathrm{III}) \mathrm{TRP}]^{4+} /\left[\mathrm{SiW}_{12} \mathrm{O}_{40}\right]^{4-}$ modified electrode and d) $[\mathrm{Ni}(\mathrm{II}) \mathrm{TRP}]^{4+} /\left[\mathrm{SiW}_{12} \mathrm{O}_{40}\right]^{4-}$ modified electrode in presence of $\mathrm{NO}_{2}{ }^{-}$in dark (dashed line) and under light irradiation of $440 \mathrm{~nm}$ (solid line). $1 \mathrm{mM} \mathrm{NaNO}_{2}$ in $0.1 \mathrm{M} \mathrm{NaClO}_{4}$ solution, $\mathrm{pH}$ 5.7, at $5 \mathrm{mVs}^{-1}$. Potentials are versus $\mathrm{Ag} / \mathrm{AgCl}$.

Figure 9: UV-vis spectra recorded from the Photolysis experiment irradiating 5 minutes consecutively until reach 25 minutes of irradiation. a) $[\mathrm{Mn}(\mathrm{III}) \mathrm{TRP}]^{5+} \mathrm{UV}$-vis spectra obtained in $\mathrm{MeOH} / \mathrm{TEA} 99: 1 \% \mathrm{v} / \mathrm{v}$ solution, b) $[\mathrm{Mn}(\mathrm{III}) \mathrm{TRP}]^{5+} \mathrm{UV}$-vis spectra obtained with the addition of $1 \mathrm{mM}$ TBAN to the solution, c) $[\mathrm{Ni}(\mathrm{II}) \mathrm{TRP}]^{4+} \mathrm{UV}$-vis spectra obtained in MeOH/TEA 99:1\% \%/v solution, d) $[\mathrm{Ni}(\mathrm{II}) \mathrm{TRP}]^{4+} \mathrm{UV}$-vis spectra obtained with the addition of $1 \mathrm{mM}$ TBAN to the solution.

Scheme 1: Probable mechanism for electrochemical reduction of nitrite mediated by [MTRP $]^{\mathrm{n}+}$

Table 1: Potential controlled electrolysis results, calculated TOF, TON and Faradaic efficiency values 
Table 2: Potential controlled electrolysis results, under light irradiation. Calculated TOF and TON and Faradaic efficiency values. 


\section{FIGURES}

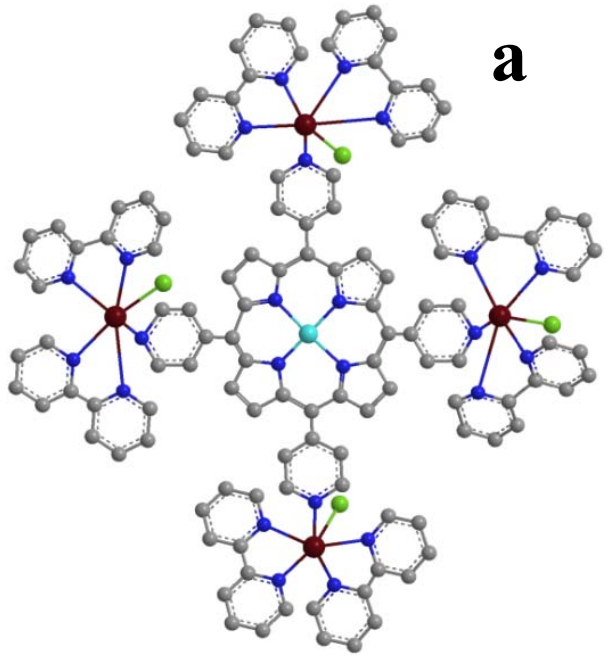

Figure

1:

a)

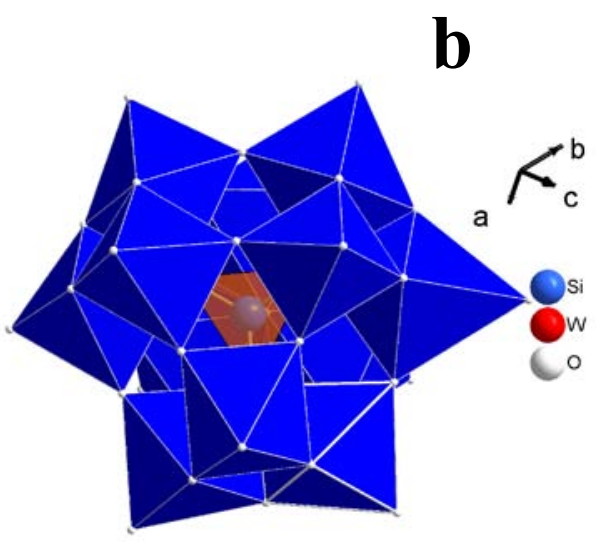

tetra(pirydil)porphyrin) $\{$ bis(bipyridine)chloride

ruthenium(II)\}

b) structure

of 


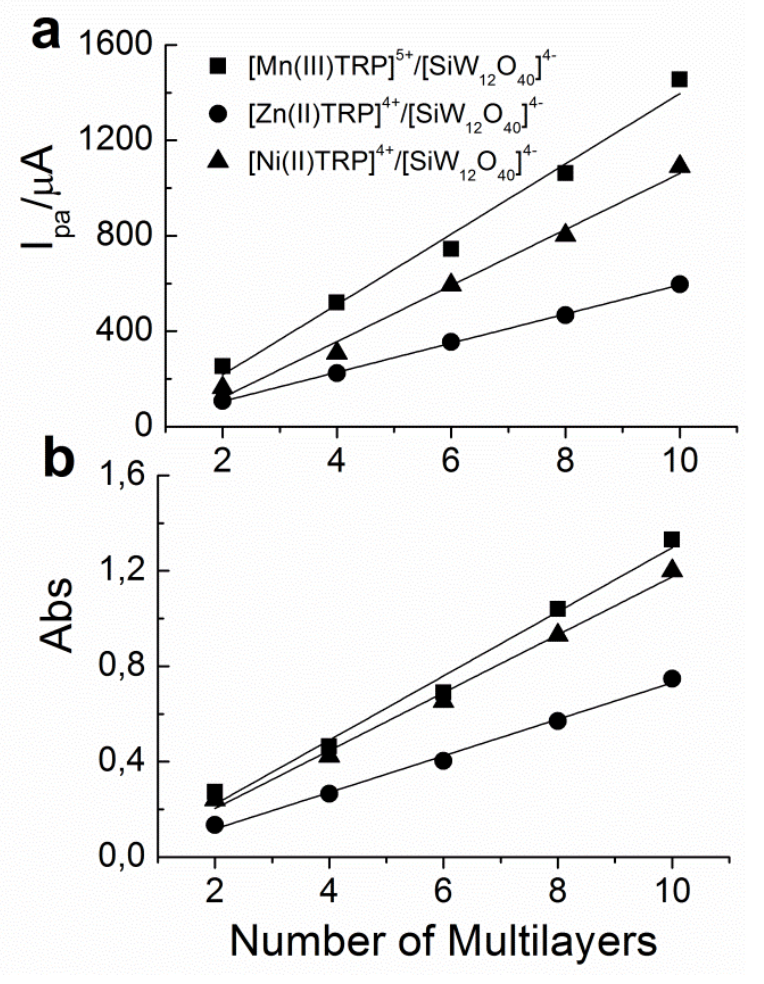

Figure 2: a) Relation between Ipa of $\mathrm{Ru}^{\mathrm{III/II}}$ process of the porphyrin and the number of bilayers. b) Relation between Abs at the Soret band and the number of bilayers. 


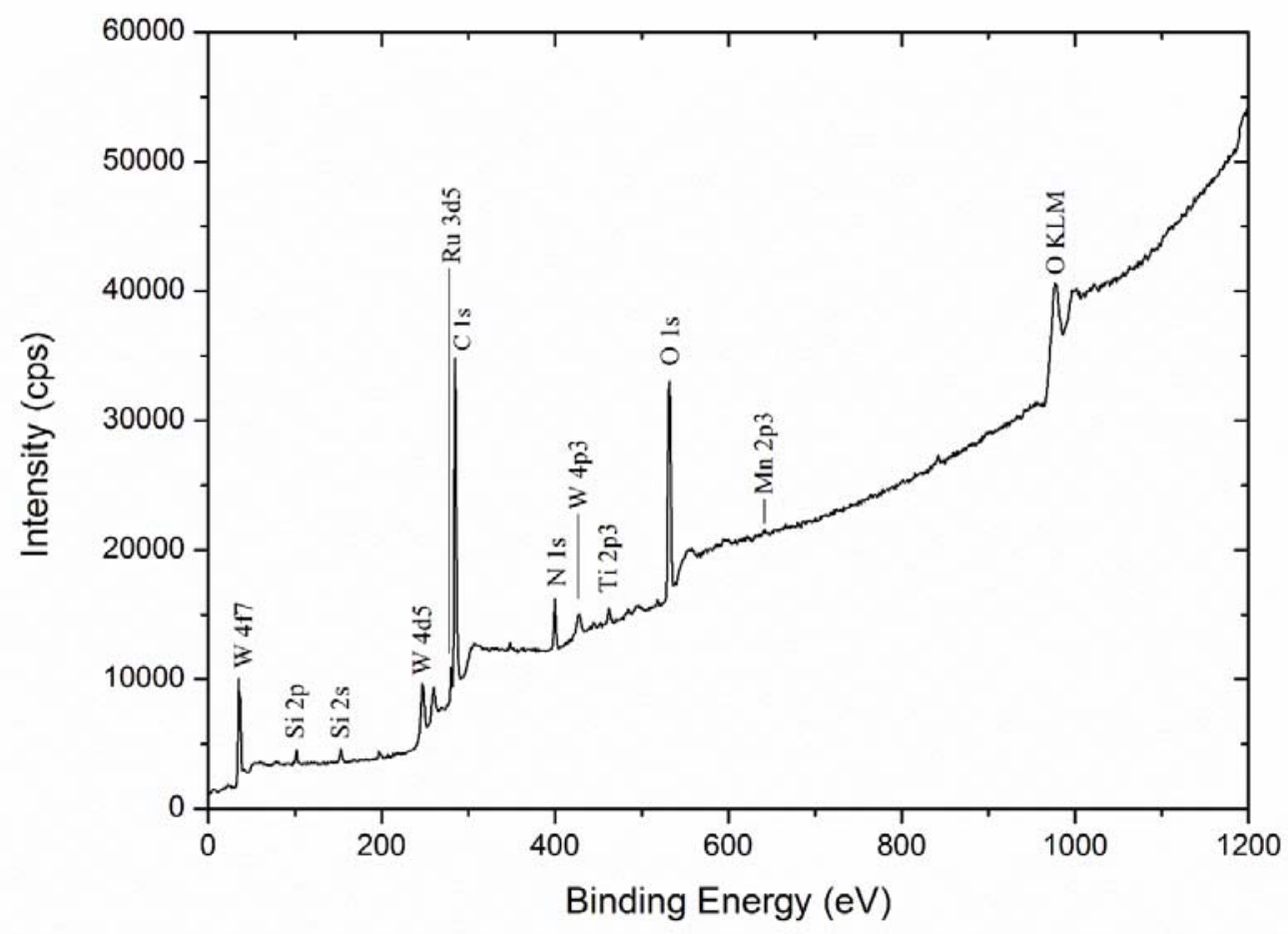

Figure 3: XPS spectrum of $[\mathrm{Mn}(\mathrm{III}) \mathrm{TRP}]^{5+} /\left[\mathrm{SiW}_{12} \mathrm{O}_{40}\right]^{4-}$ bilayer on ITO electrode. 

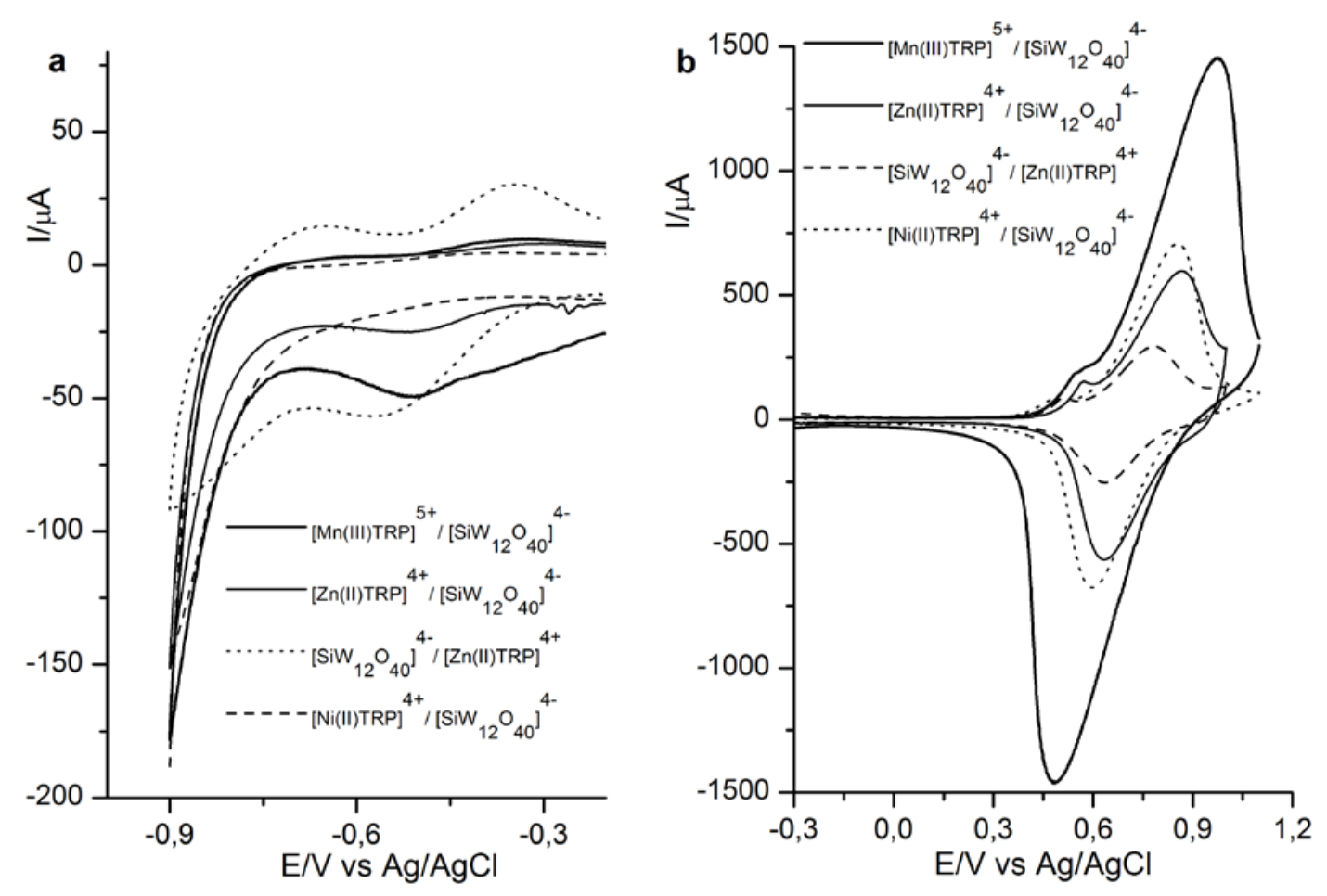

Figure 4: Voltammetric profile of $[\mathrm{Mn}(\mathrm{III}) \mathrm{TRP}]^{5+} /\left[\mathrm{SiW}_{12} \mathrm{O}_{40}\right]^{4-},[\mathrm{Ni}(\mathrm{II}) \mathrm{TRP}]^{4+} /\left[\mathrm{SiW}_{12} \mathrm{O}_{40}\right]^{4-}$ , $[\mathrm{Zn}(\mathrm{III}) \mathrm{TRP}]^{4+} /\left[\mathrm{SiW}_{12} \mathrm{O}_{40}\right]^{4-}$ and $\left[\mathrm{SiW}_{12} \mathrm{O}_{40}\right]^{4-} /[\mathrm{Zn}(\mathrm{III}) \mathrm{TRP}]^{4+}$ modified electrode a) Cathodic zone, b) anodic zone. $0.1 \mathrm{M} \mathrm{NaClO}_{4}$ solution at $100 \mathrm{mVs}^{-1}$. Potentials are versus $\mathrm{Ag} / \mathrm{AgCl}$. 


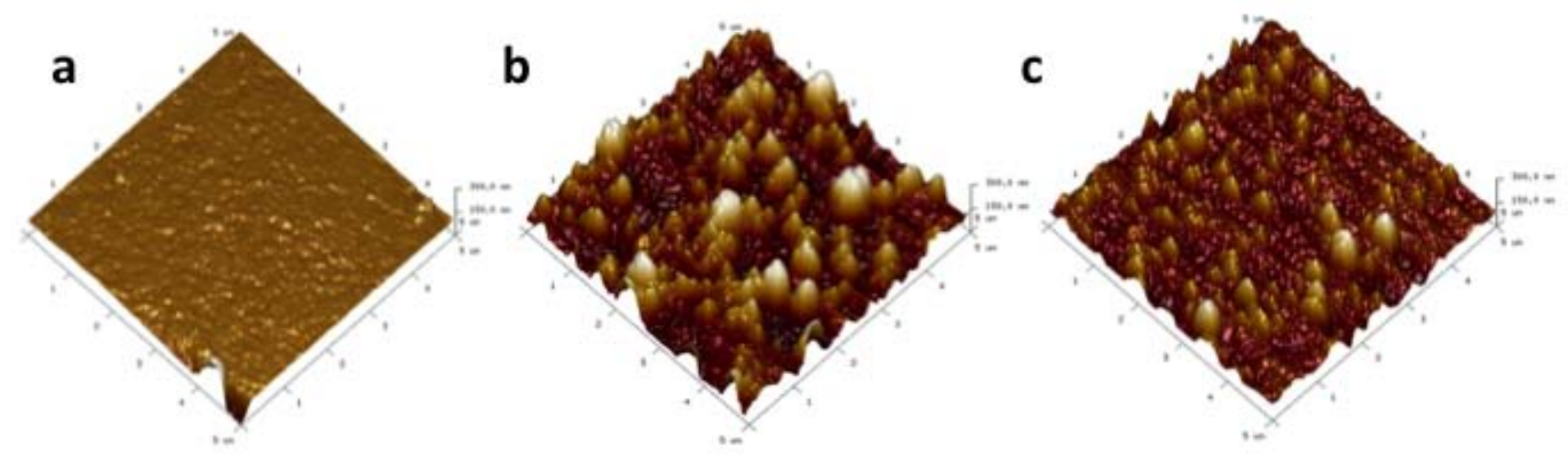

Figure 5: 3D AFM images of a) ITO electrode b) modified electrode surface with $3[\mathrm{Zn}(\mathrm{II}) \mathrm{TRP}]^{4+} /\left[\mathrm{SiW}_{12} \mathrm{O}_{40}\right]^{4}$ bilayers and c) 3 $\left[\mathrm{SiW}_{12} \mathrm{O}_{40}\right]^{4-} /[\mathrm{Zn}(\mathrm{II}) \mathrm{TRP}]^{4+}$ bilayer. 

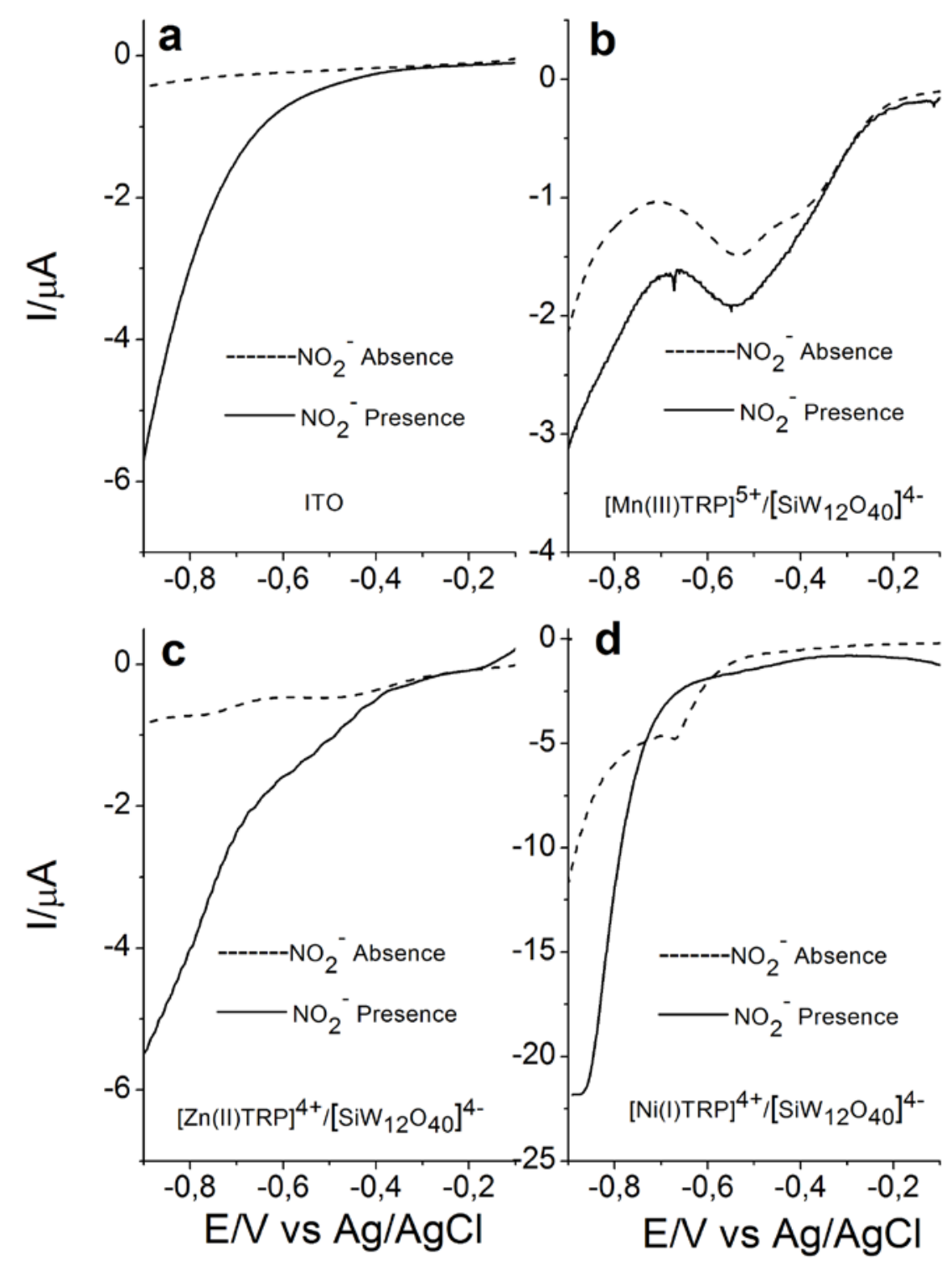

Figure 6: Linear sweep voltammogram of a) bare ITO electrode b) $[\mathrm{Mn}(\mathrm{III}) \mathrm{TRP}]^{5+} /\left[\mathrm{SiW}_{12} \mathrm{O}_{40}\right]^{4-}$ modified electrode c) $[\mathrm{Zn}(\mathrm{III}) \mathrm{TRP}]^{4+} /\left[\mathrm{SiW}_{12} \mathrm{O}_{40}\right]^{4-}$ modified electrode and d) $[\mathrm{Ni}(\mathrm{II}) \mathrm{TRP}]^{4+} /\left[\mathrm{SiW}_{12} \mathrm{O}_{40}\right]^{4-}$ modified electrode in presence (solid line) and absence (dash line) of $1 \mathrm{mM} \mathrm{NaNO}_{2}, 0.1 \mathrm{M} \mathrm{NaClO}_{4}$ solution, $\mathrm{pH}$ 5.7, at $5 \mathrm{mVs}^{-1}$. Potentials are versus $\mathrm{Ag} / \mathrm{AgCl}$. 

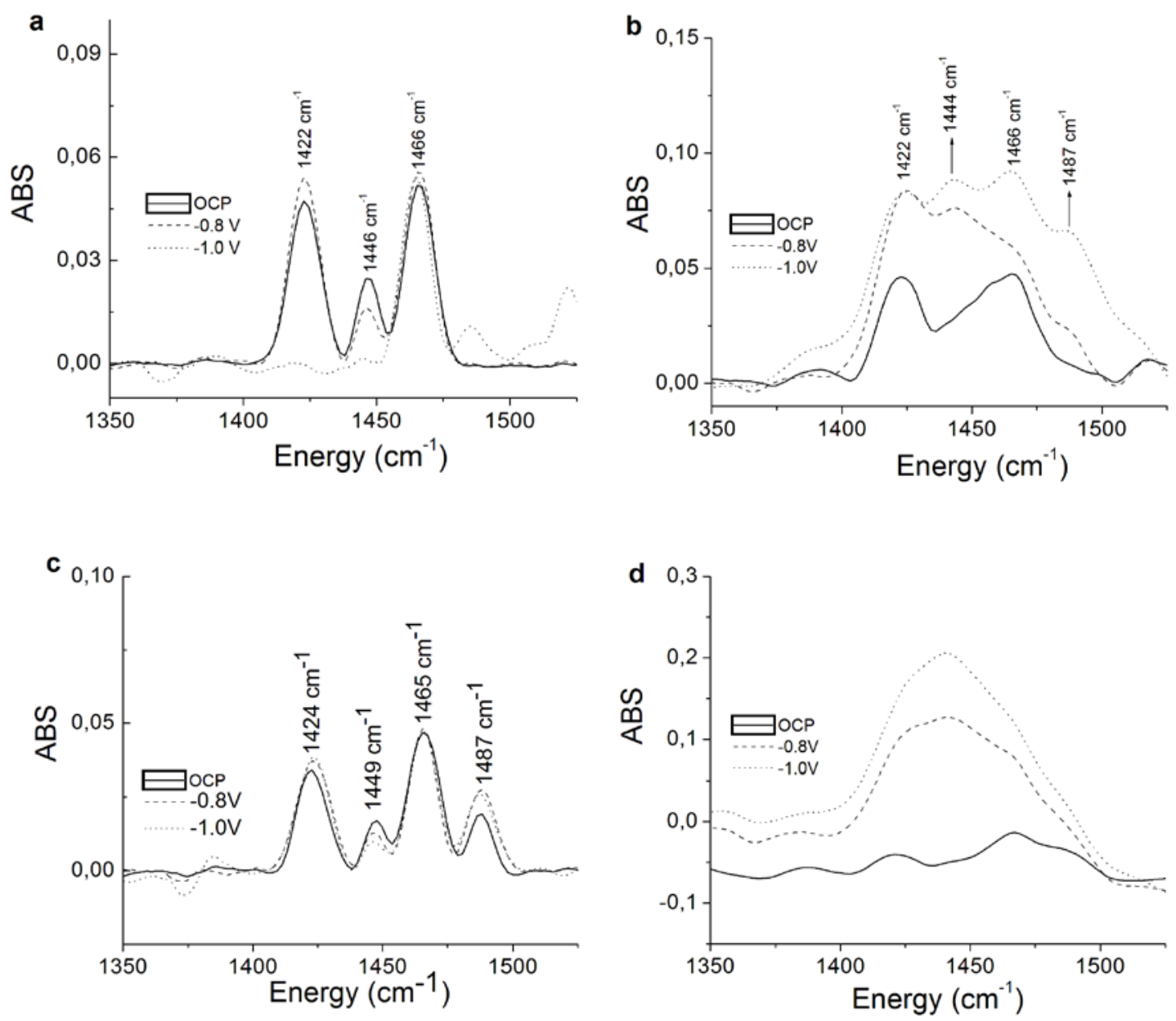

Figure 7: IR spectroelectrochemical results of a) $[\mathrm{Mn}(\mathrm{III}) \mathrm{TRP}]^{5+}$ in absence of TBAN b) $[\mathrm{Mn}(\mathrm{III}) \mathrm{TRP}]^{5+}$ in presence of TBAN c) $[\mathrm{Zn}(\mathrm{II}) \mathrm{TRP}]^{4+}$ in absence of TBAN and d) $[\mathrm{Zn}(\mathrm{II}) \mathrm{TRP}]^{4+}$ in presence of TBAN. Deuterated acetonitrile as solvent, TBAH as support electrolyte. 


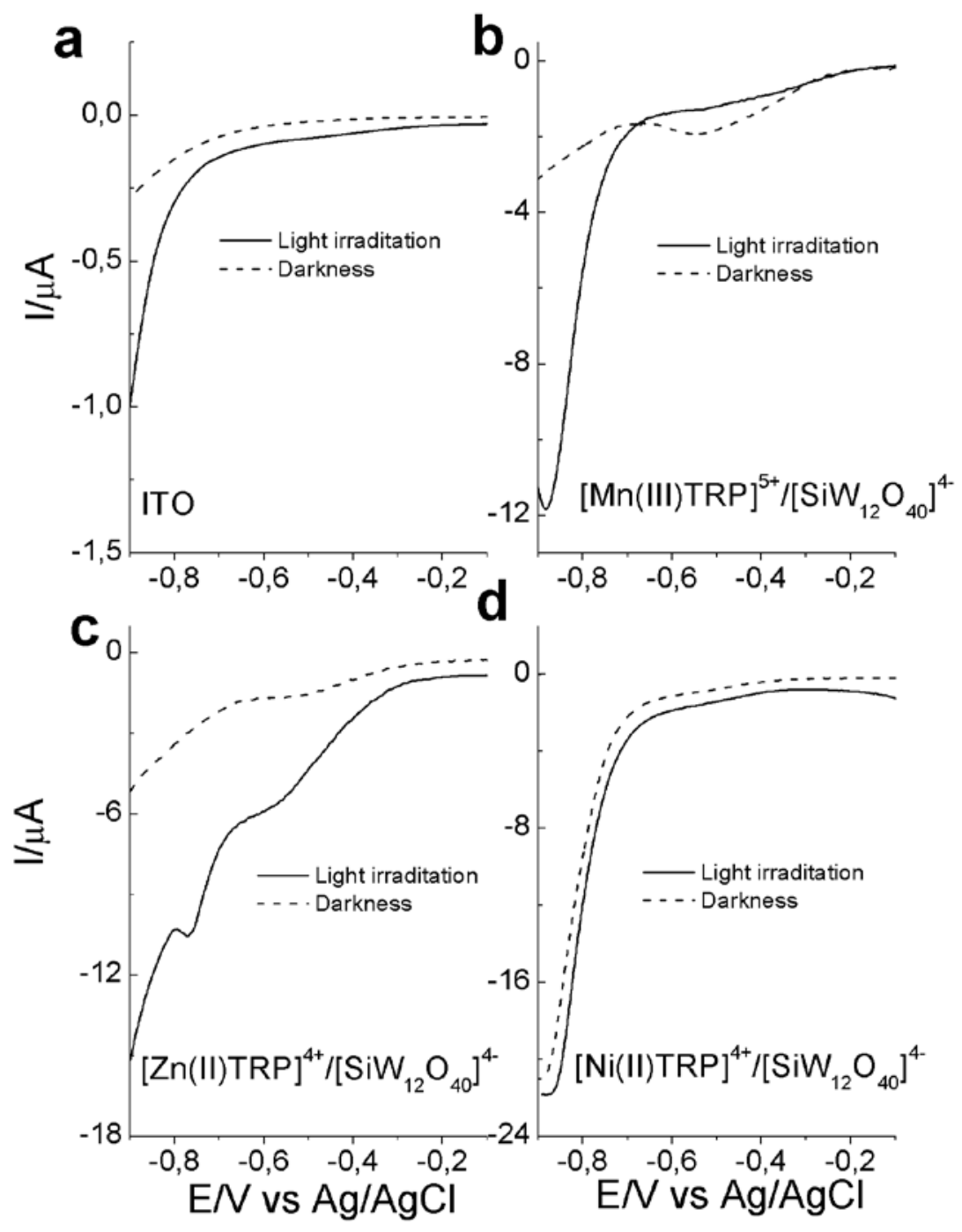

Figure 8: Linear sweep voltammogram of a) bare ITO electrode b) $[\mathrm{Mn}(\mathrm{III}) \mathrm{TRP}]^{5+} /\left[\mathrm{SiW}_{12} \mathrm{O}_{40}\right]^{4-}$ modified electrode c) $[\mathrm{Zn}(\mathrm{III}) \mathrm{TRP}]^{4+} /\left[\mathrm{SiW}_{12} \mathrm{O}_{40}\right]^{4-}$ modified electrode and d) $[\mathrm{Ni}(\mathrm{II}) \mathrm{TRP}]^{4+} /\left[\mathrm{SiW}_{12} \mathrm{O}_{40}\right]^{4-}$ modified electrode in presence of $\mathrm{NO}_{2}{ }^{-}$in dark (dashed line) and under light irradiation of 440nm (solid line). $1 \mathrm{mM} \mathrm{NaNO} 2$ in $0.1 \mathrm{M} \mathrm{NaClO}_{4}$ solution, $\mathrm{pH} 5.7$, at $5 \mathrm{mVs}^{-1}$. Potentials are versus $\mathrm{Ag} / \mathrm{AgCl}$. 
a)

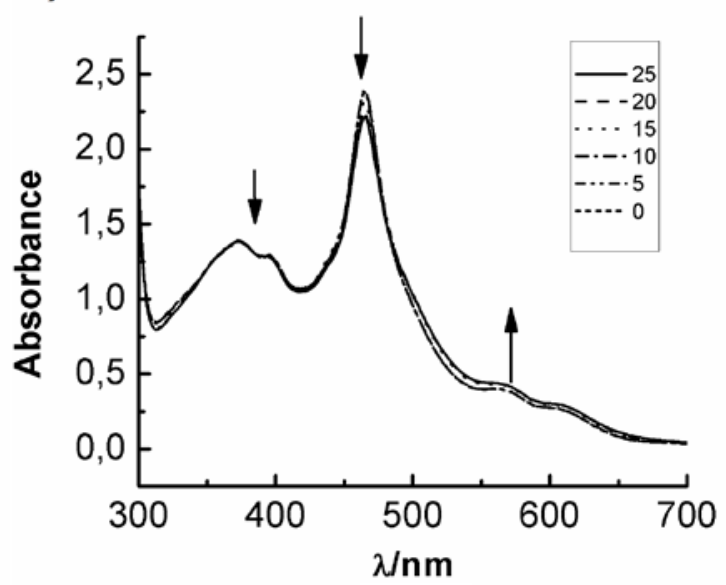

c)

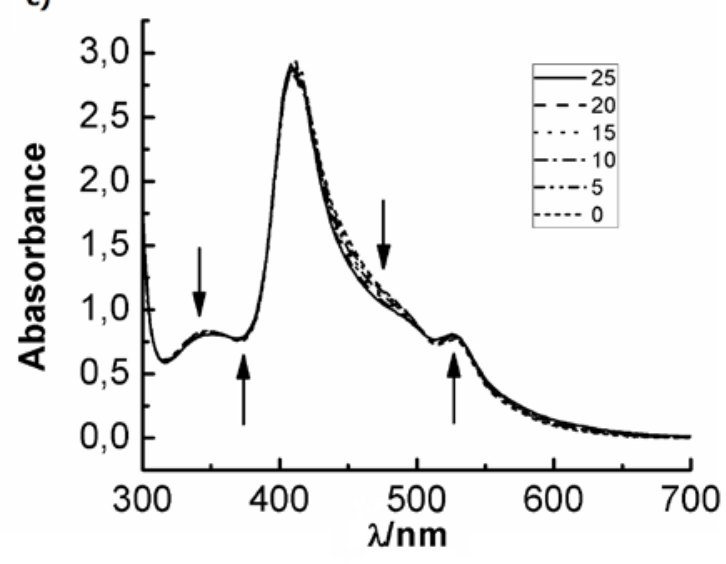

b)

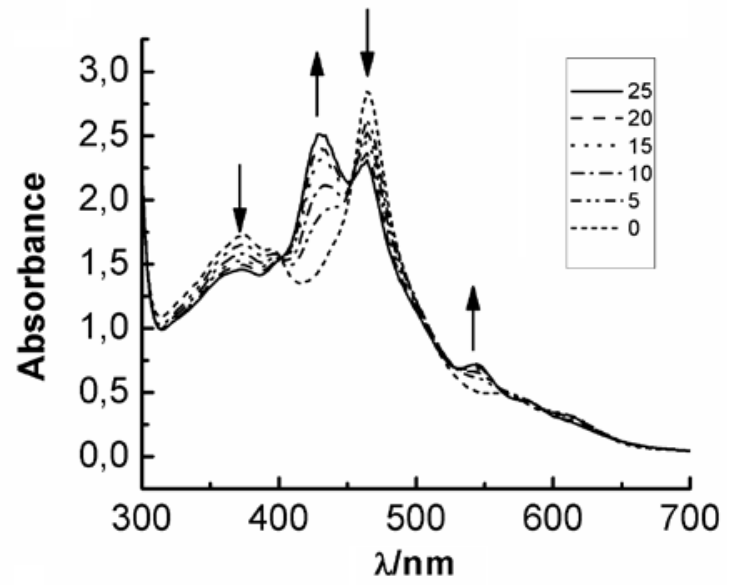

d)

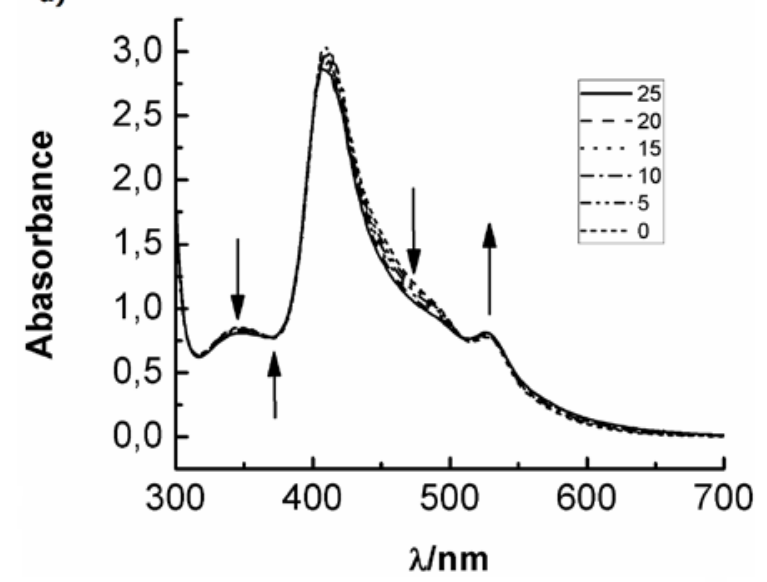

Figure 9: UV-vis spectra recorded from the Photolysis experiment irradiating 5 minutes consecutively until reach 25 minutes of irradiation. a) $[\mathrm{Mn}(\mathrm{III}) \mathrm{TRP}]^{5+} \mathrm{UV}$-vis spectra obtained in MeOH/TEA 99:1 \%v/v solution, b) $[\mathrm{Mn}(\mathrm{III}) \mathrm{TRP}]^{5+}$ UV-vis spectra obtained with the addition of $1 \mathrm{mM}$ TBAN to the solution, c) $[\mathrm{Ni}(\mathrm{II}) \mathrm{TRP}]^{4+} \mathrm{UV}$-vis spectra obtained in $\mathrm{MeOH} / \mathrm{TEA} 99: 1 \% \mathrm{v} / \mathrm{v}$ solution, d) $[\mathrm{Ni}(\mathrm{II}) \mathrm{TRP}]^{4+}$ UV-vis spectra obtained with the addition of $1 \mathrm{mM}$ TBAN to the solution. 
Table 1: Potential controlled electrolysis results, calculated TOF, TON and Faradaic efficiency values

\begin{tabular}{|c|c|c|c|c|c|c|c|c|c|}
\hline Multilayer & $\begin{array}{c}{\left[\mathrm{NH}_{2} \mathrm{OH}\right]} \\
(\mathbf{m M})\end{array}$ & $\begin{array}{c}\text { TOF }\left(\mathbf{s}^{-1}\right) \\
/ \text { TON }\end{array}$ & $\begin{array}{l}\text { Faradaic } \\
\text { efficiency }\end{array}$ & $\begin{array}{l}{\left[\mathbf{N}_{2} \mathbf{H}_{4}\right]} \\
(\mathbf{m M})\end{array}$ & $\begin{array}{c}\text { TOF }\left(\mathbf{s}^{-1}\right) \\
/ \text { TON }\end{array}$ & $\begin{array}{l}\text { Faradaic } \\
\text { efficiency }\end{array}$ & $\begin{array}{l}\left.\mathrm{NH}_{3}\right] \\
(\mathrm{mM})\end{array}$ & $\begin{array}{c}\text { TOF }\left(\mathbf{s}^{-1}\right) \\
/ \text { TON }\end{array}$ & $\begin{array}{l}\text { Faradaic } \\
\text { efficiency }\end{array}$ \\
\hline$[\mathrm{Mn}(\mathrm{III}) \mathrm{TRP}]^{5+} /\left[\mathrm{SiW}_{12} \mathrm{O}_{40}\right]^{4-}$ & $9.0 \times 10^{-1}$ & $4.7 / 148.8$ & $24,98 \%$ & 2.2 & $11.5 / 363.9$ & $48,84 \%$ & $6.6 . \times 10^{-1}$ & $3.4 / 109.2$ & $21,95 \%$ \\
\hline$[\mathrm{Zn}(\mathrm{II}) \mathrm{TRP}]^{4+} /\left[\mathrm{SiW}_{12} \mathrm{O}_{40}\right]^{4-}$ & $6.8 \times 10^{-1}$ & $3.8 / 122.6$ & $28,06 \%$ & 1.6 & $9.0 / 288.5$ & $53,03 \%$ & $7.1 \times 10^{-1}$ & $4.0 / 128.0$ & $35,26 \%$ \\
\hline$[\mathrm{Ni}(\mathrm{II}) \mathrm{TRP}]^{4+} /\left[\mathrm{SiW}_{12} \mathrm{O}_{40}\right]^{4-}$ & $5.9 \times 10^{-1}$ & $3.2 / 100.6$ & $21,01 \%$ & 1.2 & $6.5 / 204.7$ & $34,40 \%$ & $8.4 \times 10^{-1}$ & $4.5 / 143.3$ & $35,97 \%$ \\
\hline Bare ITO & $2.3 \times 10^{-1}$ & -- & $54,50 \%$ & $1 \times 10^{-2}$ & -- & $1,90 \%$ & $1.5 \times 10^{-1}$ & -- & $42,65 \%$ \\
\hline$\left[\mathrm{SiW}_{12} \mathrm{O}_{40}\right]^{4-} /[\mathrm{Zn}(\mathrm{II}) \mathrm{TRP}]^{4+}$ & --- & --- & --- & $3.8 \times 10^{-1}$ & $2.4 / 129.3$ & $38,88 \%$ & $1.6 \times 10^{-1}$ & $1.9 / 2.51 \times 10^{5}$ & $24,56 \%$ \\
\hline
\end{tabular}


Table 2: Potential controlled electrolysis results, under light irradiation. Calculated TOF and TON and Faradaic efficiency values.

\begin{tabular}{|c|c|c|c|c|c|c|}
\hline Multilayer & {$\left[\mathrm{N}_{2} \mathrm{H}_{4}\right](\mathrm{mM})$} & $\begin{array}{c}\text { TOF }\left(\mathrm{s}^{-1}\right) \\
\text { /TON }\end{array}$ & $\begin{array}{l}\text { Faradaic } \\
\text { efficiency }\end{array}$ & {$\left[\mathrm{NH}_{3}\right](\mathrm{mM})$} & $\begin{array}{c}\text { TOF }\left(\mathrm{s}^{-1}\right) \\
/ \text { TON }\end{array}$ & $\begin{array}{l}\text { Faradaic } \\
\text { efficiency }\end{array}$ \\
\hline$[\mathrm{Mn}(\mathrm{III}) \mathrm{TRP}]^{5+} /\left[\mathrm{SiW}_{12} \mathrm{O}_{40}\right]^{4-}$ & 7.1 & $100.8 / 1.6 \times 10^{6}$ & $71,49 \%$ & 1.4 & $19.9 / 3.15 \times 10^{5}$ & $21,15 \%$ \\
\hline$[\mathrm{Zn}(\mathrm{II}) \mathrm{TRP}]^{4+} /\left[\mathrm{SiW}_{12} \mathrm{O}_{40}\right]^{4-}$ & 10.0 & $155.4 / 2.4 \times 10^{6}$ & $55,72 \%$ & 1.0 & $15.5 / 2.4 \times 10^{5}$ & $52,23 \%$ \\
\hline$[\mathrm{Ni}(\mathrm{II}) \mathrm{TRP}]^{4+} /\left[\mathrm{SiW}_{12} \mathrm{O}_{40}\right]^{4-}$ & 5.7 & $83.8 / 1.3 \times 10^{6}$ & $19,44 \%$ & $9.3 \times 10^{-1}$ & $13.6 / 2.1 \times 10^{5}$ & $22,60 \%$ \\
\hline Bare ITO & $1.3 \times 10^{-1}$ & $7,02 \%--$ & & $2.2 \times 10^{-1}$ & -- & $115,8 \%$ \\
\hline
\end{tabular}

